Article

\title{
Enhancement in Productivity, Nutrients Use Efficiency, and Economics of Rice-Wheat Cropping Systems in India through Farmer's Participatory Approach
}

\author{
A. S. Panwar ${ }^{1}$, M. Shamim ${ }^{1}$, Subhash Babu ${ }^{2, *}$, N. Ravishankar ${ }^{1}$, Ashisa Kumar Prusty ${ }^{1}$, \\ N. M. Alam ${ }^{3}$, D. K. Singh ${ }^{4}$, J. S. Bindhu ${ }^{5}$, Jashanjot Kaur ${ }^{6}$, L. N. Dashora ${ }^{7}$, \\ M. D. Latheef Pasha ${ }^{8}$, Soumitra Chaterjee ${ }^{9}$, M. T. Sanjay ${ }^{10}$ and L. J. Desai ${ }^{11}$ \\ 1 ICAR-Indian Institute of Farming System Research, Modipuram, Meerut 250 110, UP, India; \\ draspanwar@gmail.com (A.S.P.); shamimagrimet@rediffmail.com (M.S.); npinpof.iifsr@icar.gov.in (N.R.); \\ aasiana143@gmail.com (A.K.P.) \\ 2 ICAR Research Complex for North Eastern Hill Region, Umiam 793 103, Meghalaya, India \\ 3 ICAR-Central Research Institute for Jute \& Allied Fibres, Barrackpore 700 120, WB, India; \\ alam.nurnabi@gmail.com \\ 4 G.B. Pant University of Agriculture and Technology, Pantnagar 263 145, Uttarakhand, India; \\ dkonweb@gmail.com \\ 5 On Farm Research Centre, Kerala Agricultural University, Trivandrum 695 522, Kerala, India; \\ jsbindhu@gmail.com \\ 6 Krishi Vigyan Kendra, Rauni 147 005, Patiala, Punjab, India; jashanjotk89@gmail.com \\ 7 Rajasthan College of Agriculture, MPUA\&T, Udaipur 313 001, Rajasthan, India; Indashora@gmail.com \\ 8 AICRP on Integrated Farming Systems, College of Agriculture, PJTSAU, Rajendranagar, Hyderabad 500030 \\ Telangana, India; lateef_pasha@rediffmail.com \\ 9 Department of Agricultural Economics, Bidhan Chandra Krishi Viswavidyalaya, Kalyani, Nadia 741 235, \\ WB, India; soumitra.soum123123@gmail.com \\ 10 Department of Agronomy, University of Agricultural Sciences, Hebbal Campus, Bangalore 560 024, \\ Karnataka, India; ecfschemebangalore@rediffmail.com \\ 11 Sardarkrushinagar Dantiwada Agricultural University, Adiya 384 255, Patan, Gujarat, India; \\ ofrsdauguj@gmail.com \\ * Correspondence: subhiari@gmail.com
}

Received: 30 October 2018; Accepted: 22 November 2018; Published: 27 December 2018

\begin{abstract}
Rice-wheat cropping system (RWCS), a lifeline for the majority of the population in South Asia is under stress, due to the imbalanced and indiscriminate use of fertilizers. Therefore, we conducted an on-farm study at eight locations (Amritsar, Katni, Nainital, Samba, Pakur, Kanpur, Ambedkarnagar, and Dindori) covering five agro climatic zones of six Indian states (Jammu and Kashmir, Punjab, Uttarakhand, Uttar Pradesh, Madhya Pradesh, and Jharkhand) to (i) calculate the partial factor productivity (PFP) and agronomic use efficiency (AUE) to judge the response of NPK and $\mathrm{Zn}$ on grain yield of rice and wheat in RWCS and (ii) to work out the economic feasibility of different combinations of NPK in rice and wheat. Seven fertilizer treatments: Control (0-0-0), N alone (N-0-0), NP (N-P-0), NK (N-0-K), NPK (N-P-K), NPK+Zn (N-P-K-Zn), and FFMP (Farmers Fertilizer Management Practice) were assigned to all the locations. The levels of applied nutrients were used as per the standard recommendation of the location. The average of all the locations showed that the use of NP enhances the grain yield of rice and wheat by $105 \%$ and $97 \%$ over control, respectively. System productivity of RWCS was expressed in terms of rice grain equivalent yield (RGEY), $\mathrm{Mg} \mathrm{ha}^{-1}$. Among the locations, Samba recorded the lowest productivity of RWCS with fertilizer treatments. In contrast, the highest productivity of RWCS with fertilizer treatments was recorded at Amritsar, except with NPK and NPK $+Z n$ fertilization, where Katni superseded the Amritsar. An approximately 3 -fold productivity gain in RWCS was recorded with the conjoint use
\end{abstract}


of NP over control across the locations. Overall, the results of our study showed that the balance application of NPK increased the productivity of RWCS $245 \%$ over control. Partial factor productivity of Nitrogen $\left(\mathrm{PFP}_{\mathrm{n}}\right) \mathrm{N}$ alone in rice varied across locations and ranged from $19 \mathrm{~kg}$ grain $\mathrm{kg}^{-1} \mathrm{~N}$ at Pakur to $41 \mathrm{~kg}_{\text {grain }} \mathrm{kg}^{-1} \mathrm{~N}$ at Amritsar. $\mathrm{PFP}_{\mathrm{n}}$ of $\mathrm{N}$ alone in wheat also ranged from $15.5 \mathrm{~kg}$ grain $\mathrm{kg}^{-1}$ of $\mathrm{N}$ at Ambedkarnagar to $28 \mathrm{~kg}_{\text {grain }} \mathrm{kg}^{-1} \mathrm{~N}$ at Amritsar. However, across locations the mean value of $\mathrm{PFP}_{\mathrm{n}}$ of $\mathrm{N}$ alone was $29 \mathrm{~kg}$ grain kg-1 $\mathrm{N}$ in rice and $21 \mathrm{~kg}$ grain kg $\mathrm{kg}^{-1} \mathrm{~N}$ in wheat. $\mathrm{PFP}_{\mathrm{n}}$ increased when combined application of $\mathrm{N}$ and $\mathrm{P}$ sorted in both rice and wheat across the locations. Similarly, combined application of NPK increased partial factor productivity of applied phosphorus ( $\mathrm{PFP}_{\mathrm{p}}$ ) in both the crops at all the locations. The combined application of NPK increased the $\mathrm{PFP}_{\mathrm{k}}$ for applied $\mathrm{K}$ at all the location. The response of $\mathrm{K}$ application with $\mathrm{N}$ and $\mathrm{P}$ when averaged over the location was $114 \%$ in rice and $93 \%$ in wheat over the combined use of $\mathrm{N}$ and $\mathrm{K}$. In our study, irrespective of fertilizer treatments, the agronomic use efficiency of applied $N\left(A_{U} E_{n}\right)$ and agronomic use efficiency of applied $\mathrm{P}\left(\mathrm{AUE}_{\mathrm{p}}\right)$ were greater in rice than in wheat across the location. With regards to the economics, the mean net monetary returns among the fertilizers treatments was minimum (INR $29.5 \times 10^{3} \mathrm{ha}^{-1}$ ) for the application of $\mathrm{N}$ alone and maximum (INR $8.65 \times 10^{3} \mathrm{ha}^{-1}$ ) for application of NPK $+\mathrm{Zn}$. The mean marginal returns across the locations was in order of $\mathrm{N}$ alone $>\mathrm{NK}>\mathrm{FFM}>$ $\mathrm{NPK}>\mathrm{NP}>\mathrm{NPK}+\mathrm{Zn}$.

Keywords: on-farm experiment; rice-wheat cropping system; partial factor productivity; agronomic use efficiency

\section{Introduction}

The rice-wheat cropping system (RWCS) is a prominent life-supporting food production system for majority of the populace in Asia, occupying an approximately 24 Mha area in Asian subtropical countries (China, India, Nepal, Bangladesh, and Pakistan) [1-3]. RWCS accounted for approximately $32 \%$ and $42 \%$ of the total rice and wheat area in these Asian countries, respectively [4]. The RWCS is indispensable for securing the food security to more than $20 \%$ of the world's population [4]. Rice and wheat are the two central pillars of food security in India, accounting for approximately $58 \%$ and $77 \%$ of the total area and food grain production in the country, respectively [5]. The majority of the Indian population lives in villages and the combined share of these two commodities accounted more than $90 \%$ of total cereal consumption in rural India [6]. However, the sustainability of rice and wheat production is under threat due to monotonous husbandry of RWCS in the same area of field. Repeated cultivation of RWCS causes excess soil nutrient mining $[3,7,8]$ and productivity fatigue. Hence, productivity enhancement of RWCS must be a prime concern to feed the rapidly increasing population of India, which is predicted to increase to 1.35 billion by 2025 [9]. Capital and energy-intensive conventional farmer's management practices for rice and wheat cultivation puts this life supporting production system on a ventilator. RWCS is practiced on diverse soil types and ecologies across the agro climatic zones of India. Including shallow to deep loamy forest and podzolic brown soils having medium to high organic matter under arid to sub-humid climates of the Western Himalayan region (WH), coarse to fine textured loam soils of semiarid to sub-humid climate of the Upper Gangetic Plains (UGP), sandy loam to clay textured soils under the moist to dry sub-humid climate of the Middle and Lower Gangetic Plains, sandy red to yellow soils under moist sub-humid to sub-humid climate of the Eastern Plateau and Hills (EPH), and mixed red to black soils under the dry sub-humid climate of Central Plateau and Hills $(\mathrm{CPH})$. Rice and wheat are grown with ample supply of irrigation water under the Trans Gangetic Plains (TGP) and UGP with a number of irrigation types: 15 to 30 in rice and three to six in wheat [3]. However, the RWCS is moderately irrigated in the middle Gangetic Plains (MGP) and Lower Gangetic Plains (LGP) [10]. In EPH and CPH regions rice is grown under a rainfed situation and wheat is grown under a restricted irrigation condition (1-3 irrigation types). Fertilizer use in 
RWCS is also highly variable across the agro climatic regions of India $[2,10]$. Both rice and wheat are heavy feeder and nutrient-exhaustive crops [3,11]. The amount of external nutrient applied to rice and wheat cannot keep pace with the amount of nutrients removed from the soil, which leads to soil and production lassitude [12,13]. The well-fertilized crops of rice and wheat meet $\sim 50.8 \%$ of their nitrogen requirements from the soil [14], which may results in poor factor productivity of RWCS [15]. The situation of nutrient mining is more alarming in the highly productive areas of the Indo Gangetic Plains (IGP) of India, where widely cultivated RWCS is supported with inadequate and unbalanced nutrient management practices [16]. Yield stagnation [17], poor water, and nutrients use efficiency [18], depletion of soil organic carbon (OC) [19], soil degradation [20], multi-nutrient deficiencies [12], and reduction in factor productivity $[7,21]$ questioned the sustainability of RWCS system. Despite of contrasting growing requirements of rice and wheat, continuous cultivation of RWCS led to the retrogression of native soil fertility and multi-nutrient deficiency [8,22]. Most Indian soils are deficient in S, Zn, M, Cu, B, and Mo [16]. Rice crops in a RWCS struggle with iron and zinc deficiency. Similarly, the succeeding wheat crop also suffers from manganese $(\mathrm{Mn})$ dearth in Punjab and boron deficiency in West Bengal [23]. Hence, the occurrence of multi micronutrient deficiencies are the new deterrent in façade of the sustainability of the RWCS, as farmers are not aware to correct the deficiencies of these yield driven nutrients. Therefore, at many locations resource poor farmers unknowingly started to use a higher amount of $\mathrm{N}$ fertilizer than the local recommendation to maintain the past yield level [24]. This kind of emerging scenario is a major culprit of the poor economic returns [25-27] of the RWCS as well as aggravating environmental pollution [28]. In general, RWCS is relatively more productive than other prevailing cropping systems in India. The problems of multi-nutrient deficiency are deceptively more severe with high yielding production systems as compared with the relatively poor yielding production systems [16,29]. Results of long-term experiments in India advocated the application of $120 \mathrm{~kg} \mathrm{~N} h a^{-1}$ to each crop in RWCS for fetching higher economic yield [30]. In RWCS, the net negative balance is $2.22 \mathrm{M} \mathrm{t}$ annum $^{-1}$ for NPK in IGP [31]. Application of NPK along with organic manures could increase SOC by $24 \%$ under continuous cropping of rice and wheat [32]. Intelligent tactics of nutrient management can improve crop productivity and SOC sequestration in cropping systems [12]. Yield exaltation in RWCS due to balance fertilization is reported by many researchers [33,34]. Hence, balance fertilization is a realistic solution to maintain the sustainability of RWCS through appropriate supply of nutrients. Balanced nutrition increases a plant's ability to absorb requisite amounts of desired nutrients and thus, improve crop productivity and input use efficiency. Apart from NP and K, the micronutrient $\mathrm{Zn}$ is the fundamental element for determining crop growth and yield. Appropriate fertilizer management strategies without excess reliance on single fertilizer use have the ability to correct the deficiency of NP and Zn - the most limiting nutrients in the rice-wheat soils. Cultivators' fields of major rice-wheat growing areas are fragmented and typically small with huge spatial variability in management strategies. Large variations in soil nutrient balance and nutrient requirements of the RWCS exist among the agro climatic zones mainly due to crop management's practices, which influence the attainable crop yields greatly [3]. Rice-wheat growers in India often apply a greater amount of nitrogen fertilizers, but overlook the adequate application of other nutrients, particularly phosphorus, potash, and micronutrients [13]. Across the rice-wheat growing areas of India the yield and nutrient application gap is very wide between on-station and on-farm experiments [3]. Blanket fertilizer application over large areas is typical in RWCS areas, which leads to inefficient utilization of applied nutrients and other production inputs [35]. Hence, the field-specific nutrient needs of crops should be tailored with fertilizer application for harnessing the optimum nutrients use efficiency of applied nutrients. Most of the nutrients management studies in RWCS were conducted in on-station experiments in IGP. Information on the benefit of balance fertilization application on productivity of RWCS based on multi-location trials especially outsides of IGP on farmer's fields across the rice-wheat growing areas in India is very scarce. The study of crop modeling and simulation is an important area in the prediction of crop performance behavior under changing management practices in diverse regions; as the performance and behavior of crop models is 
primarily made through comparison of simulated and observed variables. Pezzuolo et al. [36] showed the possibility of using the SALUS model to evaluate the performance of crops and energy output to crop and soil management conditions with long-term predictions up to 2025 in USA. Similarly, authors of another past paper [37] evaluated the impact of climatic trends and variability based on 25 to 30 years of observed data in RWCS using DSSAT in IGP of India and found very good agreement between the observed and simulated yield of rice and wheat. Hence, the data generated in this study may be useful for simulation and modeling studies for long-term policy formulations for sustainable development of RWCS. We, therefore, conducted scientifically-designed farmer-managed farm experiments with rice and wheat in system mode, representing a range of contrasting locations in India, with the following objectives, to (i) determine the grain yield of rice and wheat with per $\mathrm{kg}$ application of nutrients (NPK and Zn), (ii) make a comparative assessment on yield of rice and wheat with the combined and balanced application of NPK and Zn over farmers' fertilizer management practices and N alone, and (iii) conduct a profitability assessment and/or financial budgeting of nutrients use.

\section{Materials and Method}

\subsection{Study Region}

Data employed in this study were taken from on-farm experiments conducted with rice and wheat between 2016 to 2017 in the Indian districts of Samba in the Jammu \& Kashmir state, Amritsar in the Punjab state, Nainital in the Uttarakhand state, Kanpur and Ambedkarnagar in the Uttar Pradesh state, Pakur in the Jharkhand state, and Katni and Dindori in the Madhya Pradesh state (Figure 1) under the umbrella of the All India Coordinated Research Project (AICRP) on Integrated Farming Systems (IFS) On-Farm Research (OFR) by the Indian Council of Agricultural Research (ICAR)-Indian Institute of Farming Systems Research, Modipuram, UP, India. Among the tested locations, Amritsar, Kanpur, and Ambedkarnagar are located in the Indo Gangetic Plain (IGP) where the RWCS is a principal food production system. However, Samba, Nainital, Pakur, Katni, and Dindori are located outside IGP where the RWCS is an emerging production system. The locations chosen for the study represent diversity in soils, climatic conditions, and fertilizer application by the growers (Table 1). 


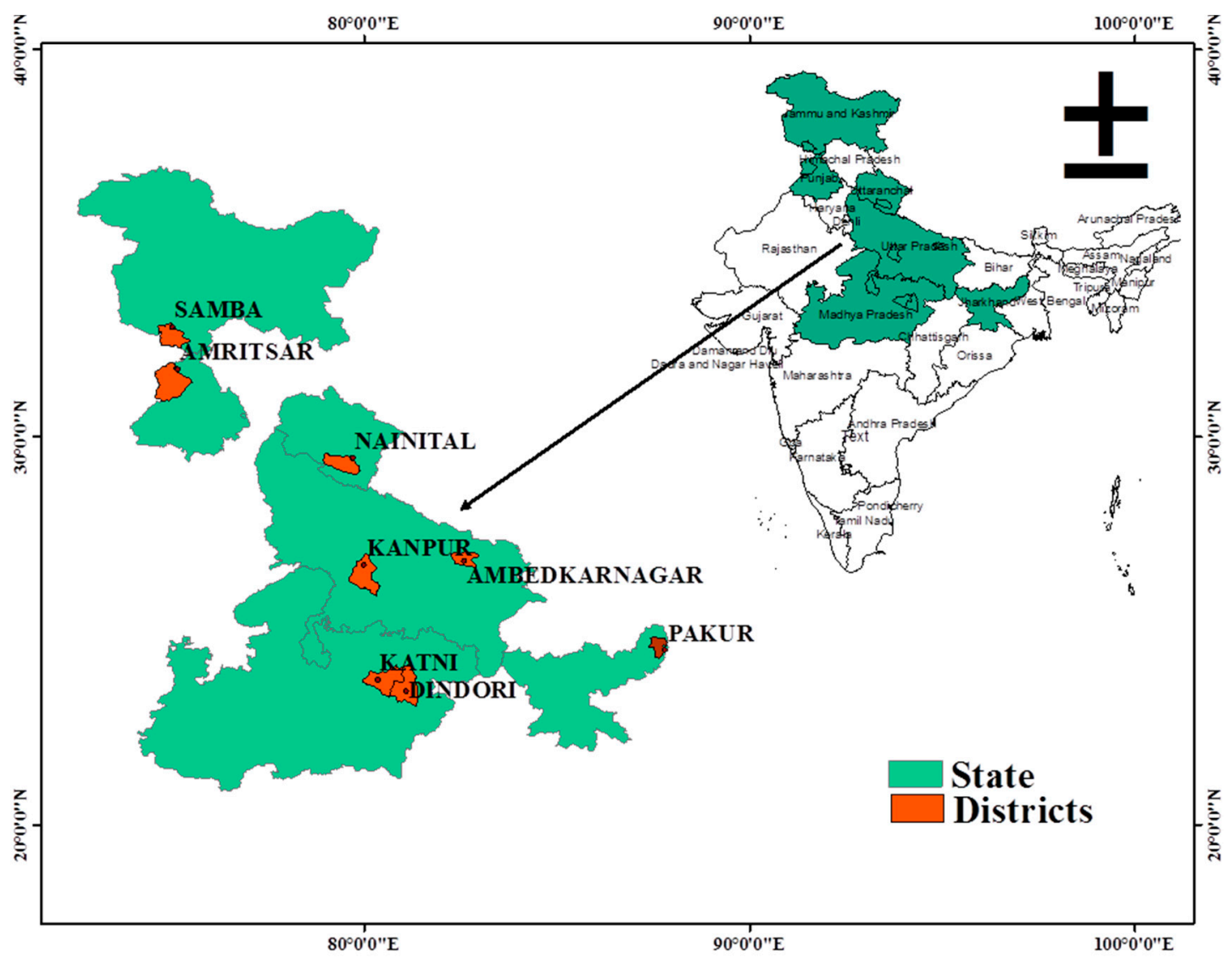

Figure 1. Map showing the locations of the farm experiments across six states in India. 
Table 1. Characteristics of farmers' fields with on-farm experiments at eight locations in India.

\begin{tabular}{|c|c|c|c|c|c|c|c|c|}
\hline Characteristics & Amritsar & Katni & Nainital & Samba & Pakur & Kanpur & Ambedkarnagar & Dindori \\
\hline State & Punjab & $\begin{array}{l}\text { Madhya } \\
\text { Pradesh }\end{array}$ & Uttarakhand & $\begin{array}{l}\text { Jammu \& } \\
\text { Kashmir }\end{array}$ & Jharkhand & Uttar Pradesh & Uttar Pradesh & $\begin{array}{l}\text { Madhya } \\
\text { Pradesh }\end{array}$ \\
\hline $\begin{array}{l}\text { Agro Climatic } \\
\text { Zone }\end{array}$ & $\begin{array}{c}\text { Trans Gangetic } \\
\text { Plain }\end{array}$ & $\begin{array}{c}\text { Central Plateau } \\
\text { and Hill }\end{array}$ & $\begin{array}{c}\text { Western } \\
\text { Himalayan }\end{array}$ & $\begin{array}{l}\text { Western } \\
\text { Himalayan }\end{array}$ & $\begin{array}{l}\text { Eastern Plateau } \\
\text { and Hills }\end{array}$ & $\begin{array}{c}\text { Upper } \\
\text { Gangetic Plain }\end{array}$ & $\begin{array}{c}\text { Middle } \\
\text { Gangetic Plain }\end{array}$ & $\begin{array}{c}\text { Eastern Plateau } \\
\text { and Hills }\end{array}$ \\
\hline Latitude & $31.6340^{\circ} \mathrm{N}$ & $23.8308^{\circ} \mathrm{N}$ & $29.3803^{\circ} \mathrm{N}$ & $32.5530^{\circ} \mathrm{N}$ & $24.6337^{\circ} \mathrm{N}$ & $26.4499^{\circ} \mathrm{N}$ & $26.4684^{\circ} \mathrm{N}$ & $22.8457^{\circ} \mathrm{N}$ \\
\hline Longitude & $74.8723^{\circ} \mathrm{E}$ & $80.4072^{\circ} \mathrm{E}$ & $79.4636^{\circ} \mathrm{E}$ & $75.1108^{\circ} \mathrm{E}$ & $87.8501^{\circ} \mathrm{E}$ & $80.3319^{\circ} \mathrm{E}$ & $82.6915^{\circ} \mathrm{E}$ & $81.0755^{\circ} \mathrm{E}$ \\
\hline Elevation(masl) & 229 & 427 & 2288 & 314.2 & 151.3 & 109 & 285 & 229 \\
\hline $\begin{array}{l}\text { Average annual } \\
\text { Rainfall, mm }\end{array}$ & 712 & 1171 & 1831 & 1157 & 1550 & 802 & 1029 & 1377 \\
\hline \multicolumn{9}{|c|}{ Farmers' fertilizer use for rice $\left(\mathrm{kg} \mathrm{ha}^{-1}\right)$} \\
\hline $\mathrm{N}$ & $150 \pm 4.31$ & $80 \pm 2.89$ & $100 \pm 4.61$ & $50 \pm 2.82$ & $60 \pm 2.24$ & $200 \pm 4.27$ & $120 \pm 2.43$ & $50 \pm 2.20$ \\
\hline $\mathrm{P}$ & $30 \pm 1.12$ & $30 \pm 1.86$ & $60 \pm 2.63$ & $10 \pm 1.41$ & $30 \pm 1.32$ & $60 \pm 2.77$ & $30 \pm 1.47$ & $23 \pm 0.91$ \\
\hline K & 0 & 0 & 0 & 0 & 0 & 0 & 0 & 0 \\
\hline $\mathrm{Zn}$ & 0 & 0 & 0 & 0 & 0 & 0 & $10 \pm 0.31$ & 0 \\
\hline \multicolumn{9}{|c|}{ Farmers' fertilizer use for wheat $\left(\mathrm{kg} \mathrm{ha}^{-1}\right)$} \\
\hline $\mathrm{N}$ & $150 \pm 4.27$ & $80 \pm 2.62$ & $100 \pm 2.76$ & $50 \pm 3.22$ & $60 \pm 2.57$ & $140 \pm 4.47$ & $120 \pm 2.58$ & $60 \pm 2.32$ \\
\hline $\mathrm{P}$ & $30 \pm 2.41$ & $30 \pm 1.65$ & $40 \pm 1.93$ & $20 \pm 1.98$ & $30 \pm 1.74$ & $60 \pm 2.05$ & $30 \pm 1.34$ & $23 \pm 1.84$ \\
\hline K & 0 & 0 & 0 & 0 & 0 & 0 & 0 & 0 \\
\hline $\mathrm{Zn}$ & 0 & 0 & 0 & 0 & 0 & 0 & $10 \pm 26$ & 0 \\
\hline \multicolumn{9}{|c|}{ Soil texture, $\mathrm{pH}$, organic carbon, and available NPK status of farmers field before commencement of on farm experiments } \\
\hline Soil texture & Sandy loam & Clay loam & Sandy loam & Sandy loam & Clay loam & Sandy loam & Sandy loam & Clay loam \\
\hline $\mathrm{pH}$ & $7.75 \pm 0.04$ & $7.2 \pm 0.11$ & $6.56 \pm 0.03$ & $7.23 \pm 0.03$ & $5.7 \pm 0.12$ & $7.92 \pm 0.05$ & $7.49 \pm 0.07$ & $7.32 \pm 0.06$ \\
\hline OC (\%) & $0.40 \pm 0.06$ & $0.66 \pm 0.10$ & $0.71 \pm 0.01$ & $0.53 \pm 0.01$ & $0.56 \pm 0.01$ & $0.41 \pm 0.01$ & $0.44 \pm 0.02$ & $0.59 \pm 0.01$ \\
\hline $\mathrm{N}\left(\mathrm{kg} \mathrm{ha}{ }^{-1}\right)$ & $250 \pm 2.31$ & $254 \pm 4.66$ & $278 \pm 4.17$ & $228.99 \pm 2.41$ & $292 \pm 5.08$ & $187 \pm 3.70$ & $178 \pm 5.85$ & $250 \pm 4.92$ \\
\hline $\mathrm{P}\left(\mathrm{kg} \mathrm{ha}^{-1}\right)$ & $31 \pm 0.90$ & $10 \pm 0.48$ & $18 \pm 0.67$ & $14.63 \pm 0.07$ & $5 \pm 0.31$ & $13 \pm 0.52$ & $16 \pm 0.34$ & $12 \pm 1.01$ \\
\hline $\mathrm{K}\left(\mathrm{kg} \mathrm{ha}^{-1}\right)$ & $142 \pm 1.32$ & $341 \pm 14.88$ & $181 \pm 2.90$ & $122.19 \pm 1.00$ & $158 \pm 3.12$ & $143 \pm 0.95$ & $173 \pm 5.07$ & $324 \pm 5.12$ \\
\hline
\end{tabular}


Amritsar, located in the Trans Gangetic Plains (TGP) of IGP has a semiarid climate with temperatures ranging from $0{ }^{\circ} \mathrm{C}$ to $42{ }^{\circ} \mathrm{C}$. However, the average maximum and minimum annual temperature are $30.4^{\circ} \mathrm{C}$ and $15.5^{\circ} \mathrm{C}$, respectively. In general, January is a coolest month and May is the warmest month. Annual rainfall is $\sim 712$ millimeters $(\mathrm{mm})$. Soils are alluvial in origin and low in organic C, nitrogen, and phosphorus. Gross cropped area is 0.42 Mha. The cropping intensity is $194 \%$. The average productivity of rice and wheat in the district are $2907 \mathrm{~kg} \mathrm{ha}^{-1}$ and $4049 \mathrm{~kg} \mathrm{ha}^{-1}$, respectively. Rice, wheat, maize, rapeseed, mustard, and cotton are the principal field crops in the region.

Kanpur is located in Upper Gangetic Plain (UGP) of IGP has dry-summer subtropical climates often referred to as "Mediterranean" and alluvial soils. The average annual maximum temperature is $32.2{ }^{\circ} \mathrm{C}$; whereas the minimum temperature is $\sim 19.2{ }^{\circ} \mathrm{C}$. The average amount of rainfall is $801.5 \mathrm{~mm}$. The warmest month is May, with an average temperature of $41.3^{\circ} \mathrm{C}$, and the coolest month is January, with an average temperature of $8.5^{\circ} \mathrm{C}$. The gross cropped area of Kanpur is 0.266 Mha with an average cropping intensity of $113 \%$. The average yield of rice and wheat are $2286 \mathrm{~kg} \mathrm{ha}^{-1}$ and $3107 \mathrm{~kg} \mathrm{ha}^{-1}$, respectively. Rice, maize, sorghum, wheat, gram, rapeseed, and mustard are the major field crops of the area.

Katni is located in Central Plateau and Hill region $(\mathrm{CPH})$ has hot sub-humid dry climate. The average amount of rainfall is $1171.4 \mathrm{~mm}$. May is the hottest month in the year with a maximum temperature of $42{ }^{\circ} \mathrm{C}$ and January is the coolest month with minimum temperature of $9{ }^{\circ} \mathrm{C}$. The soils are alluvium in origin. The gross cropped area is $0.25 \mathrm{Mha}$ with average cropping intensity of $128 \%$. The average yield of rice and wheat are $734 \mathrm{~kg} \mathrm{ha}^{-1}$ and $1005 \mathrm{~kg} \mathrm{ha}^{-1}$, respectively. Rice, wheat, gram, linseed, lentil, pea, maize, and seasamum are the major field crops of the area.

Ambedkarnagar located in the Middle Gangetic Plain (MGP) of IGP has a hot sub-humid climate. The soils of the district are alluvium in origin and categorized as new alluvium (locally known as Khadar) and old alluvium (locally known as Bhangar); the average annual rainfall is $1028.9 \mathrm{~mm}$. The gross cropped area is 0.28 Mha with average cropping intensity of $169 \%$. The average yield of rice and wheat are $2637 \mathrm{~kg} \mathrm{ha}^{-1}$ and $3279 \mathrm{~kg} \mathrm{ha}^{-1}$, respectively. Rice, sugarcane, wheat, pea, potato, and rapeseed and mustard are the major field crops of the region.

Samba located in Western Hill region (WH) has a warm humid climate with a hot dry summer and cold winter. The average annual rainfall is $1156.5 \mathrm{~mm}$ with annual maximum and minimum temperature of $29.5^{\circ} \mathrm{C}$ and $17.8^{\circ} \mathrm{C}$, respectively. Soils are light sandy/loam in texture. At high altitude soils are sparse and full of gravels but the soils of the valleys are alluvial in nature. The gross cropped area is 60.26 Mha with an average cropping intensity of $211 \%$. The average yield of rice and wheat are $1875 \mathrm{~kg} \mathrm{ha}^{-1}$ and $1739 \mathrm{~kg} \mathrm{ha}^{-1}$, respectively. Rice, wheat, maize, and millets are the major field crops of the region.

Nainital, also located in $\mathrm{WH}$, has a subtropical highland climate with a relatively cool summer and severe winter. The soils are sandy to loamy in texture with shallow to moderately shallow in depth. July is hottest month with a temperature range of $16.4^{\circ} \mathrm{C}$ to $23.5^{\circ} \mathrm{C}$, while January is the coldest month with a temperature range of $1.7^{\circ} \mathrm{C}$ to $10.7^{\circ} \mathrm{C}$. The average annual rainfall is $1831.2 \mathrm{~mm}$. Soils are light sandy to alluvial loam in nature. The gross cropped area is $0.075 \mathrm{Mha}$ with an average cropping intensity of $156 \%$. The usual productivity of rice and wheat are $2100 \mathrm{~kg} \mathrm{ha}^{-1}$ and $2450 \mathrm{~kg} \mathrm{ha}^{-1}$, respectively. Rice, wheat, soybean, maize, sugarcane, potato, mustard, gram, and millets are the major field crops of the region.

Pakur is located in EPH and has a humid to sub-humid climate with red and black soils. The maximum temperature in Pakur reaches up to $40{ }^{\circ} \mathrm{C}$ during the month of May. In contrast the minimum temperature falls to $4{ }^{\circ} \mathrm{C}$ during December. The average amount of rainfall is $1550 \mathrm{~mm}$. The gross cropped area is 0.063 Mha with average cropping intensity of $107 \%$. The average yield of rice and wheat are $1413 \mathrm{~kg} \mathrm{ha}^{-1}$ and $1550 \mathrm{~kg} \mathrm{ha}^{-1}$, respectively. Rice, wheat, pigeon pea, gram, black gram, and lentil are the major field crops of the region.

Dindori is also located in EPH and has a hot sub-humid climate with a moderate winter and severe summers as well as well-distributed rainfall received from southwest monsoon. The average 
amount of rainfall is $1376.7 \mathrm{~mm}$. The soils are alluvial in nature. The minimum temperature in the higher hills decreases 2 to $3{ }^{\circ} \mathrm{C}$ during the winter months, whereas the maximum temperature in valley areas goes beyond $45^{\circ} \mathrm{C}$ during the peak summer month. The gross cropped area is 0.27 Mha with average cropping intensity of $135 \%$. The average productivity of rice and wheat are $825 \mathrm{~kg} \mathrm{ha}^{-1}$ and $606 \mathrm{~kg} \mathrm{ha}^{-1}$, respectively. Rice, wheat, soybean, maize, black gram, millets, niger, gram, and lentil are the major field crops of the region.

The farmer's field where RWCS has been practiced for more than 10 consecutive years were selected to ensure that the research findings were relevant to long-term RWCS and not baffled by rotation and fertilizer management with other crops having different input demands. A stratified random sampling technique was used for selecting the experimental unit at every location. At all the locations every selected farmer was interviewed between May and June of 2016 to examine their current crop and nutrients management practices. Among the locations the wide variation were observed in crop management practices and in nutrient use (Table 1). The average annual production $\left(\mathrm{kg} \mathrm{ha}^{-1}\right)$ of RWCS (rice + wheat) across the locations was in the order of Amritsar $>$ Ambedkarnagar $>$ Kanpur $>$ Nainital $>$ Samba $>$ Pakur $>$ Katni $>$ Dindori.

\subsection{Treatments and Crop Management}

Experiments were conducted between 2016 and 17 at 152 farmer's fields in eight districts (locations) under the jurisdiction of six Indian states representing five diverse agro climatic zones of India. The numbers of cultivator's fields selected for evaluation purpose in various districts were twenty four in each of Amritsar, Kanpur, Nainital, and Pakur whereas twenty in Ambedkarnagar, and twelve in each of Dindori, Katni, and Samba. Seven fixed plots $\left(100 \mathrm{~m}^{2}\right.$ each) were demarcated in every farmer's field to evaluate a set of seven fertilizer treatments both in rice and wheat, the fertilizer treatments were Control (no fertilizer application), N alone (N-0-0-0), NP (N-P-0-0), NK (N-0-K-0), NPK (N-P-K-0), NPK and Zn (N-P-K-Zn), and Farmers fertilizer management practices (FFMP). As per the treatments the recommended dose of nitrogen $(\mathrm{N})$, phosphorus $(\mathrm{P})$, potassium $(\mathrm{K})$, and zinc $(\mathrm{Zn})$ was applied to both the crops under investigation except absolute control, where no application of fertilizers (nutrients) was sorted. The fertilizer treatments were assigned to rice crop randomly in each plot ensuring that the same level of fertilizer has come in subsequent wheat crop of the system.

All fertilizer treatments were applied in the recommended dose except in FFMP (Table 2). Fertilizers used as a source of nutrients included urea [CO $\left.\left(\mathrm{NH}_{2}\right)_{2}\right]$ containing $46 \% \mathrm{~N}$, Single superphosphate $\left[\mathrm{Ca}\left(\mathrm{H}_{2} \mathrm{PO}_{4}\right)_{2}\right]$ containing $16 \% \mathrm{P}_{2} \mathrm{O}_{5}$, potassium chloride $[\mathrm{KCl}]$ containing $60 \% \mathrm{~K}_{2} \mathrm{O}$, and zinc Sulfate $\left[\mathrm{ZnSO}_{4} .7 \mathrm{H}_{2} \mathrm{O}\right.$ ] containing $21 \% \mathrm{Zn}$. In rice, a full dose of $\mathrm{P}, \mathrm{K}$, and $\mathrm{Zn}$ and a half dose of $\mathrm{N}$ were applied as basal; the remaining half dose of $\mathrm{N}$ was applied at panicle initiation stage. However, in wheat, the full dose of $\mathrm{P}, \mathrm{K}$, and $\mathrm{Zn}$ along with one third dose of $\mathrm{N}$ were applied as basal and the remaining amount of $\mathrm{N}$ was applied in two equal splits at crown root initiation (CRI) and at anthesis at all the locations. Except for fertilizer treatment imposition, farmers used their own cultural practices and resources for growing both crops. The details of genotypes and transplanting/sowing time of rice and wheat in different locations are given in Table 3. Researchers recorded the yield data and collected the soil sample for assessing the preliminary fertility status before the commencement of on-farm experiments in individual plots across the tested locations. An approximately 25 day-old rice seedling was transplanted ubiquitously. Before the transplanting of rice, farmers ploughed, puddled, and levelled their field to ensure better crop establishment. Two seedlings of rice per hill were planted at $2 \mathrm{~cm}$ depth with a planting geometry of $15 \times 15 \mathrm{~cm}$. 
Table 2. Recommended levels of fertilizers N, P, K, and Zn $\left(\mathrm{kg} \mathrm{ha}^{-1}\right)$, genotype grown and date of transplanting/sowing of rice, and wheat at different locations in India.

\begin{tabular}{|c|c|c|c|c|c|c|c|c|c|c|c|c|}
\hline \multirow{3}{*}{ Location } & \multicolumn{6}{|c|}{ Rice } & \multicolumn{6}{|c|}{ Wheat } \\
\hline & \multirow[t]{2}{*}{ Genotype } & \multicolumn{4}{|c|}{ Recommended Levels of Nutrients } & \multirow[t]{2}{*}{ Date of Transplanting } & \multirow[t]{2}{*}{ Genotype } & \multicolumn{4}{|c|}{ Recommended Levels of Nutrients } & \multirow[t]{2}{*}{ Date of Sowing } \\
\hline & & $\mathrm{N}$ & $\mathrm{P}$ & K & $\mathrm{Zn}$ & & & $\mathrm{N}$ & $\mathrm{P}$ & K & $\mathrm{Zn}$ & \\
\hline Amritsar & PR124 & 120 & 30 & 30 & 25 & 15-18 June 2016 & HD 3086 & 120 & 60 & 30 & 25 & 15-20 Nov 2016 \\
\hline Nainital & NPH 567 & 150 & 60 & 60 & 25 & 1-25 July 2016 & HD2967 & 150 & 40 & 40 & 10 & 15 Nov-10 Dec 2016 \\
\hline Samba & B-370 & 30 & 20 & 10 & 25 & 15 June-20 July 2016 & WH1105 & 100 & 50 & 25 & 20 & 15 Nov 2016-1 Jan 2017 \\
\hline Pakur & Naveen & 100 & 50 & 25 & 25 & 20-25 July 2016 & K-9107 & 100 & 50 & 25 & 10 & 25 Nov-1 Dec 2016 \\
\hline Kanpur & PHB-71 & 150 & 60 & 40 & 25 & 10-20 July 2016 & K-1006 & 120 & 60 & 40 & 20 & 15-20 Nov 2016 \\
\hline Ambedkarnagar & Sarju-52 & 150 & 60 & 60 & 25 & 10-25 July 2016 & HD 3086 & 150 & 60 & 40 & 25 & 15 Nov-18 Dec 2016 \\
\hline Dindori & MTU1010 & 120 & 60 & 40 & 25 & 10-18 July 2016 & GW 366 & 120 & 60 & 40 & 10 & 15 Nov-10 Dec 2016 \\
\hline
\end{tabular}

Table 3. Effect of $\mathrm{N}, \mathrm{P}, \mathrm{K}$, and $\mathrm{Zn}$ on grain yield of rice and wheat $\left(\mathrm{Mg} \mathrm{ha}^{-1}\right)$ at farmer's field across the locations in India.

\begin{tabular}{|c|c|c|c|c|c|c|c|c|c|c|c|c|c|c|c|c|}
\hline \multirow{2}{*}{ Location } & \multicolumn{8}{|c|}{ Rice } & \multicolumn{8}{|c|}{ Wheat } \\
\hline & Control & $\mathbf{N}$ & NP & NK & NPK & NPK Zn & FFMP & LSD (5\%) & Control & $\mathbf{N}$ & NP & NK & NPK & NPK Zn & FFMP & $\operatorname{LSD}(5 \%)$ \\
\hline Amritsar & 2.97 & 4.92 & 5.46 & 5.16 & 5.92 & 6.43 & 6.04 & 0.48 & 2.41 & 3.44 & 3.87 & 3.67 & 4.29 & 4.62 & 4.36 & 0.34 \\
\hline Katni & 1.68 & 3.02 & 3.91 & 3.28 & 5.98 & 6.65 & 3.58 & 0.24 & 1.69 & 2.82 & 3.78 & 3.04 & 5.55 & 6.15 & 3.51 & 0.19 \\
\hline Nainital & 2.78 & 3.55 & 4.87 & 4.37 & 5.58 & 5.75 & 3.92 & 0.25 & 2.45 & 3.31 & 4.16 & 3.82 & 4.91 & 5.15 & 3.61 & 0.25 \\
\hline Samba & 1.25 & 1.66 & 2.26 & 1.99 & 2.66 & 2.74 & 2.18 & 0.10 & 1.25 & 1.62 & 2.33 & 2.03 & 2.80 & 2.89 & 2.20 & 0.15 \\
\hline Pakur & 0.88 & 1.88 & 2.94 & 2.17 & 3.46 & 3.56 & 2.19 & 0.14 & 0.70 & 1.64 & 2.85 & 1.95 & 3.30 & 3.39 & 2.09 & 0.09 \\
\hline Kanpur & 2.29 & 3.25 & 4.89 & 3.90 & 5.41 & 5.82 & 3.85 & 0.18 & 2.02 & 2.43 & 3.24 & 2.86 & 3.72 & 3.92 & 3.31 & 0.76 \\
\hline Ambedkarnagar & 1.62 & 3.18 & 3.95 & 3.52 & 4.35 & 4.66 & 3.64 & 0.14 & 1.12 & 2.26 & 2.92 & 2.57 & 3.28 & 3.48 & 2.78 & 0.12 \\
\hline Dindori & 1.96 & 2.64 & 3.50 & 3.25 & 4.01 & 4.46 & 2.83 & 0.37 & 1.89 & 2.82 & 3.46 & 3.39 & 4.17 & 4.40 & 3.03 & 0.36 \\
\hline Mean & 1.93 & 3.01 & 3.95 & 3.47 & 4.67 & 5.01 & 3.53 & - & 1.69 & 2.54 & 3.33 & 2.92 & 4.00 & 4.25 & 3.11 & - \\
\hline
\end{tabular}


Weed infestation is a major problem in rice-based production systems and threatens system productivity [38]. The farmers of Pakur, Katni, Kanpur, and Dindori practiced one-two manual weeding to reduce the weed menace. However, farmers of Amritsar, Samba, Nainital, and Ambedkarnagar applied Butachlor (N-butoxymethyl-2-chloro-2', $6^{\prime}$-diethylacetanilide) @ $3.0 \mathrm{~L} \mathrm{ha}^{-1}$ followed by one manual weeding to minimize the losses due to weeds in rice. The rice crop was grown with irrigation at all locations except at Katni, Dindori, and Pakur. Rice was harvested manually with sickle, leaving approximately 10 to $15 \mathrm{~cm}$ stubbles in the field. After rice, the plough layer $(10-15 \mathrm{~cm})$ of soil was tilled three to four times with a tractor-drawn harrow and cultivator at Amritsar, Kanpur, Ambedkarnagar, and Pakur, whereas at Nainital and Samba soil was tilled five to six times with a power tiller and at Dindori and Katni, a good tilth was prepared using bulk drawn plough and cultivators.

After harvest of rice, wheat was sown at the rate of $125 \mathrm{~kg}$ seed ha ${ }^{-1}$ at $4-5 \mathrm{~cm}$ depth maintaining $22.5 \mathrm{~cm}$ spacing between the rows using a tractor drawn seed drill at Amritsar and Kanpur. At other locations, wheat was sown by broadcasting followed by planking to cover the seeds. With regards to the weed management in wheat, farmers followed two to three manual weeding at Dindori and Pakur. Whereas, farmers of Kanpur, Ambedkarnagar, Nainital, Samba, and Katni practiced one hand weeding and one chemical weeding (use of Isoproturon at the rate of $1 \mathrm{~kg} \mathrm{ha}^{-1}$ ) to manage the weeds in wheat. However, farmers of Amritsar supplemented one hand weeding with axial (Pinoxaden + Cloquintocet-Mexyl) at the rate of $50 \mathrm{~g} \mathrm{ha}^{-1}$ to minimize the losses due to weeds in wheat. Wheat was harvested manually with help of iron sickle retaining $5 \mathrm{~cm}$ of stubbles in the field at Dindori, Katni, Pakur, Nainital, and Samba. At Amritsar, Ambedkarnagar and Kanpur farmers used diesel-operated combine harvesters leaving $\sim 15 \mathrm{~cm}$ crop stubbles in the field. Grain and straw yields of rice and wheat were determined from a $20 \mathrm{~m}^{2}$ area in each pre-demarcated plots. After three days sun-drying in the field, the total biomass (grain + straw) was weighed and threshed. Grain yields were reported at $14 \%$ moisture content in both rice and wheat. Straw yields were reported on a dry weight basis.

\subsection{Soil Analysis}

Before the initiation of on-farm experiments during Kharif 2016 at all the locations, soil samples were collected from the plough layer $(0-15 \mathrm{~cm}$ depth) at ten places in each of the 152 farmer's fields. Collected soil samples were mixed thoroughly and well-homogenized by using a pestle and mortar and passed through a $100-\mathrm{mm}$ sieve to eliminate the undesired material, afterwards the representative sample was drawn for chemical analysis. Soils were analyzed for organic carbon (Walkley and Black method), extractable $\mathrm{N}$ (alkaline $\mathrm{KMNO}_{4}$ method) suggested by Subbiah [39], extractable P $(0.5 \mathrm{M}$ $\mathrm{NaHCO}_{3}, \mathrm{pH} 8.5$ extraction) [40], and extractable $\mathrm{K}$ (1 M NH $4 \mathrm{OAc}, \mathrm{pH} 7.0$ extraction) [41]. Particle size analysis was conducted by the International Pipette method.

\subsection{Estimation of Nutrients Use Efficiencies}

Nutrient use efficiency (NUE) is an innovative and ultimate concept to evaluate the sustainability and profitability of cropping systems, mainly affected by fertilizer managements. In this study we have estimated the NUE in terms of Partial Factor Productivity (PFP) and Agronomic Use Efficiency (AUE) of applied nutrients. PFP is a production efficiency calculated in unit of crop yield harvested per unit of nutrient applied however; AUE was calculated to quantify the effect of one unit application of a particular nutrient on economic yield enhancement. For applied NP and K, PFP and AUE were calculated using the following equations.

$$
\begin{gathered}
\operatorname{PFP}_{n}=G Y_{n} / F_{n} \\
\operatorname{PFP}_{p}=\left(G Y_{n p}-G Y_{n}\right) / F_{p} \\
\operatorname{PFP}_{k}=\left(G Y_{n k}-G Y_{n}\right) / F_{k} \\
\operatorname{AUE}_{n}=\left(G Y_{n}-G Y_{0}\right) / F_{n}
\end{gathered}
$$




$$
\begin{aligned}
& A U E_{p}=\left(G Y_{n p k}-G Y_{n k}\right) / F_{p} \\
& A U E_{k}=\left(G Y_{n p k}-G Y_{n p}\right) / F_{k}
\end{aligned}
$$

where, $\mathrm{PFP}_{\mathrm{n}}, \mathrm{PFP}_{\mathrm{p}}$, and $\mathrm{PFP}_{\mathrm{k}}$ are the partial factor productivity of $\mathrm{NP}$ and $\mathrm{K}$, respectively, $\mathrm{AUE}_{\mathrm{n}}, \mathrm{AUE}_{\mathrm{p}}$, and $\mathrm{AUE}_{\mathrm{k}}$ agronomic use efficiency of $\mathrm{N}, \mathrm{P}$, and $\mathrm{K}$, respectively. $\mathrm{GY}_{0}, \mathrm{GY}_{\mathrm{n}}, \mathrm{GY}_{\mathrm{np}}, \mathrm{GY}_{\mathrm{nk}}$, and $\mathrm{GY}_{\mathrm{npk}}$ are the yields of the respective treatments (control, $\mathrm{N}$ alone, $\mathrm{N}$ with $\mathrm{P}, \mathrm{N}$ with $\mathrm{K}, \mathrm{N}$ with $\mathrm{P}$ and $\mathrm{K}, \mathrm{NPK}+\mathrm{Zn}$, and farmer fertilizer management practice) and $\mathrm{F}_{\mathrm{n}}, \mathrm{F}_{\mathrm{p}}$, and $\mathrm{F}_{\mathrm{k}}$ are the amounts of applied $\mathrm{N}, \mathrm{P}$, and $\mathrm{K}$, respectively. The quantity of all nutrients input and economic outputs are expressed in $\mathrm{kg} \mathrm{ha}^{-1}$.

Association between control plot yields $\left(\mathrm{Y}_{0}\right)$ and soil organic carbon $(\mathrm{OC})$, native NPK contents in soil were established by least square linear regression. The contribution of OC (\%), native $\mathrm{N}, \mathrm{P}$, and $\mathrm{K}$ to $Y_{0}$ was determined by the following equation.

$$
\mathrm{Y}=\mathrm{b}_{0}+\mathrm{b}_{1} \mathrm{~W}+\mathrm{b}_{2} \mathrm{X}+\mathrm{b}_{3} \mathrm{Y}+\mathrm{b}_{4} \mathrm{Z}
$$

where, $Y$ is estimated $Y_{0}, b_{0}, b_{1}, b_{2}, b_{3}$, and $b_{4}$ are the constant and $W, X, Y$, and $Z$ and are soil organic carbon, inherent available $\mathrm{N}, \mathrm{P}$, and $\mathrm{K}$ status in the soil. $\mathrm{Y}_{0}, \mathrm{X}, \mathrm{Y}$, and $\mathrm{Z}$ are expressed in $\mathrm{kg} \mathrm{ha}^{-1}$, while $\mathrm{W}$ in percentage.

\subsection{Financial Budgeting}

Financial budgeting of the different fertilizers treatments was done by marginal analysis. The cost of cultivation for rice and wheat was calculated on the basis of different crop management practices performed and input used (field preparation, seed, nursery raising and transplanting in case of rice, sowing in case of wheat, fertilizer management, irrigation, weed management, harvesting, threshing, and drying). Added net return for fertilization with NPK and Zn relative to FFMP was determined using the minimum support prices (MSP) of rice and wheat, declared by Government of India during 2016. Comparisons of yield for the entire RWCS were made on system rice grain equivalent yield (SRGEY) $\mathrm{Mg} \mathrm{ha}^{-1}$.

$$
\text { SRGEY }=R G Y+\frac{W G Y X P W G}{P R G}
$$

where, $\mathrm{RGY}=$ rice grain yield $(\mathrm{kg}), \mathrm{WGY}=$ wheat grain yield $(\mathrm{kg}), \mathrm{PRG}=\mathrm{MSP}$ of rice grain $\left(\mathrm{INR} \mathrm{kg}{ }^{-1}\right)$, and $\mathrm{PWG}=$ MSP of wheat grain $\left(\mathrm{INR} \mathrm{kg}{ }^{-1}\right)$.

Gross returns, net returns, B:C ratio of different treatments, and marginal returns (MR) of the given fertilizer treatment over control was calculated as per the following equations.

$$
\begin{gathered}
\mathrm{n} \\
\mathrm{GMR}=\sum_{\mathrm{i}=1}(\mathrm{RY}+\mathrm{RS}) \\
\mathrm{n} \\
\mathrm{NMR}=\sum_{\mathrm{i}=1}(\mathrm{GMR}-\mathrm{C}) \\
\mathrm{n} \\
\mathrm{BC}=\sum_{\mathrm{i}=1}(\mathrm{GMR} / \mathrm{C}) \\
\end{gathered}
$$

where, GMR, gross monetary returns; RY, monetary returns from seed yield; RS, monetary return from straw; NMR, Net monetary return; C, Cost of production; and BC, Benefit:Cost (B:C Ratio).

$$
\mathrm{MR}=\frac{\mathrm{NMR}_{\mathrm{t}}-\mathrm{NMR}_{\mathrm{c}}}{\mathrm{CC}_{\mathrm{t}}-\mathrm{CC}_{\mathrm{c}}} \times 100
$$

where, $\mathrm{NMR}_{\mathrm{t}}$ and $\mathrm{NMR}_{\mathrm{c}}$ are net monetary returns of treatment and control, respectively, while $\mathrm{CC}_{\mathrm{t}}$ and $\mathrm{CC}_{\mathrm{c}}$ are the cost of cultivation of treatment and control plots, respectively. 


\subsection{Statistical Analysis}

Farmer fields were considered as a replication at each location and Randomized Block Design (RBD) was used for statistical comparisons. Descriptive statistical analysis was used for different parameters to establish the range of variability and deviation with in location using standard error of mean. Thereafter, the Randomized Block Design was used to compare treatment means within and between the locations [42]. The SAS (11.0 version) statistical tool was used for quantifying the location difference in the measured variables and presence of differences with in the treatment were tested with in the ANOVA by Fisher's F-test at 0.05 level of significance. When location and treatment interaction was significant it was compared with least significant difference (LSD) at the $5 \%$ level of significance. In this study we used the stepwise regression analysis technique to identify the most prominent yield affecting soil nutrients (NPK) and OC under zero external input supply condition.

\section{Results}

\subsection{Effect of NPK and Zn on Grain Yield of Rice and Wheat}

Grain yield of rice and wheat responded positively with the application of nutrients over control at all locations (Table 3). However, the highest grain yield of both the crops was recorded with balance fertilization of NPK along with Zn. Among the locations, the highest improvement in yield of both rice and wheat was recorded at Katni. Averaged grain yield of rice and wheat over the location showed that, application of $\mathrm{N}$ alone recorded $\sim 55 \%$ higher rice grain yield, $50 \%$ higher wheat grain yield over control. The yield advantage due to $\mathrm{N}$ application over control varied from $28 \%$ (Nainital) to $114 \%$ (Pakur) in rice and $20 \%$ (Kanpur) to $134 \%$ (Pakur) in wheat. Application of $\mathrm{N}$ and $\mathrm{P}$ also exerted the significant effect on grain yield of both the crops at all the location, grain yield of rice and wheat enhances $105 \%$ and $97 \%$ over the control, respectively. The response of combined application of $\mathrm{N}$ and $\mathrm{P}$ varied from $75 \%$ (Nainital) to $234 \%$ (Pakur) in rice and $60 \%$ (Kanpur) to $307 \%$ (Pakur) in wheat. Combined application of $\mathrm{N}$ with $\mathrm{K}$ also followed similar yield enhancement trends over the control however, yield improvement could not keep pace with the combined application of $\mathrm{N}$ and $\mathrm{P}$. The application of $\mathrm{N}$ with $\mathrm{K}$ increases the grain yield of rice and wheat by $80 \%$ and $73 \%$ over the control, respectively. Similarly, the average yield advantage at all locations due to combined application of NPK was $142 \%$ in rice and $137 \%$ in wheat over control. However, yield response of NPK varied from 99 to $293 \%$ in rice and 78 to $371 \%$ in wheat. The minimum and maximum yield advantage in both the crops due to NPK fertilizer treatment was noticed at Amritsar and Pakur, respectively. Application of NPK with Zn was over-yielded about $160 \%$ in rice and $152 \%$ in wheat compared to control. Averaged of all the locations showed that the plots received NPK with Zn fertilizers has recorded $160 \%$ higher grain yield of rice and $152 \%$ higher grain yield of wheat over the control. However, combined response of these fertilizer treatments varies from 107\% (Nainital) to 305\% (Pakur) in rice and 92\% (Amritsar) to $384 \%$ (Pakur) in wheat over control.

\subsection{Effect of NPK and Zn on System Productivity of RWCS}

System productivity of RWCS was assessed in terms of rice grain equivalent yield (RGEY), $\mathrm{Mg} \mathrm{ha}^{-1}$. Among the locations, Samba recorded the lowest productivity of RWCS with fertilizer treatments (Figure 2). In contrast, the highest productivity of RWCS with fertilizer treatments was recorded at Amritsar, except with NPK and NPK $+Z n$ fertilization, where Katni supersedes Amritsar. Application of $\mathrm{N}$ exerted a significant effect on RGEY and on an average a 106\% productivity enhancement was recorded over the control across the locations. The yield improvement due to $\mathrm{N}$ application varied from $31 \%$ at Samba to $122 \%$ at Pakur over control. An approximately 3-fold productivity gain in RWCS was recorded with combined application of $\mathrm{N}$ and $\mathrm{P}$ over control across the locations; although, the increase in system productivity ranged from 83 to $265 \%$ over the control. Average productivity enhancement due to $\mathrm{N}$ and $\mathrm{K}$ imposition across the locations was $153 \%$, however between the locations wide variations in productivity due to $\mathrm{N}$ and $\mathrm{K}$ fertilizer was also observed. 
Minimum improvement in system productivity due to $\mathrm{N}$ and $\mathrm{K}$ was observed at Kanpur (57\% over control) and the maximum was observed at Pakur (160\% over control). Balance application of NP and $\mathrm{K}$ proves its superiority over the single application of these macronutrients and recorded $245 \%$ enhancement in system productivity over control. However, the maximum (326\% over control) and minimum (89\% over control) improvement in RGEY due to NP and K application was recorded at Pakur and Amritsar, respectively. Inclusion of $\mathrm{Zn}$ in fertilizers schedule again geared the productivity of RWCS at all the locations over control. Averaged of all the location revealed that the application of NPK and Zn resulted in $255 \%$ productivity enhancement of RWCS over control. However, response of these nutrients over the control varied among the locations, the maximum response (328\%) was recorded at Pakur, while the lowest was at Amritsar (105\%).

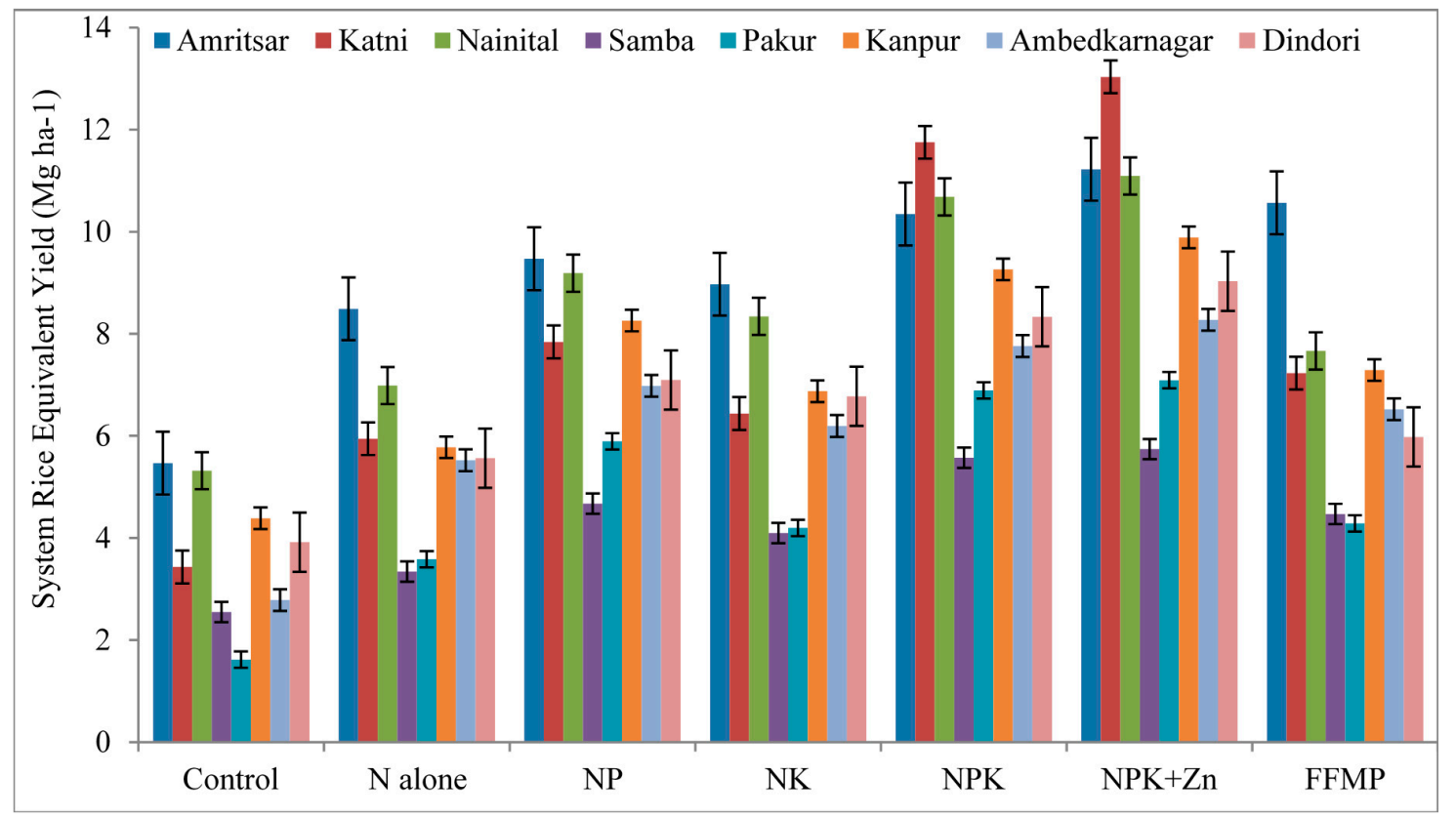

Figure 2. Effect of NPK and Zn on system rice equivalent yield (SREY) $\mathrm{Mg}^{-1}$ at farmer's field across the locations in India (Vertical bar indicates LSD at $\mathrm{P}=0.05$ ).

\subsection{Effect of NPK on PFP of RWCS}

$\mathrm{PFP}_{\mathrm{n}}$ of $\mathrm{N}$ alone in rice varied across the location and ranged from $19 \mathrm{~kg}_{\text {grain }} \mathrm{kg}^{-1} \mathrm{~N}$ at Pakur to $41 \mathrm{~kg}$ grain $\mathrm{kg}^{-1} \mathrm{~N}$ at Amritsar (Table 4). $\mathrm{PFP}_{\mathrm{n}}$ of $\mathrm{N}$ alone in wheat also ranged from $15.5 \mathrm{~kg}$ grain $\mathrm{kg}^{-1}$ of $\mathrm{N}$ at Ambedkarnagar to $28 \mathrm{~kg}_{\text {grain }} \mathrm{kg}^{-1} \mathrm{~N}$ at Amritsar. However, across the locations the mean value of $\mathrm{PFP}_{\mathrm{n}}$ of $\mathrm{N}$ alone was $29 \mathrm{~kg}_{\text {grain kg }}{ }^{-1} \mathrm{~N}$ in rice and $21 \mathrm{~kg}$ grain kg ${ }^{-1} \mathrm{~N}$ in wheat. $\mathrm{PFP}_{\mathrm{n}}$ increases when combined application of $\mathrm{N}$ and $\mathrm{P}$ sorted in both rice and wheat across the locations. The combined effect of $\mathrm{N}$ and $\mathrm{P}$ recorded an average $31 \%$ and $29 \%$ higher $\mathrm{PFP}_{\mathrm{n}}$ over the $\mathrm{N}$ alone in rice and wheat, respectively. However, the combined effect of $\mathrm{N}$ and $\mathrm{P}$ on $\mathrm{PFP}_{\mathrm{n}}$ varied from location to location. The lowest value of $\mathrm{PFP}_{\mathrm{n}}$ of rice with $\mathrm{P}$ was at Amritsar $\left(9 \mathrm{~kg}\right.$ grain kg $\left.{ }^{-1} \mathrm{~N}\right)$ and the highest at Pakur ( $\left.35.9 \mathrm{~kg}_{\text {grain }} \mathrm{kg}^{-1} \mathrm{~N}\right)$. In contrast, the lowest value of $\mathrm{PFP}_{\mathrm{n}}$ was with $\mathrm{P}$ in wheat at Ambedkarnagar $\left(19 \mathrm{~kg}_{\text {grain }} \mathrm{kg}^{-1} \mathrm{~N}\right)$ and the highest at Amritsar $\left(32 \mathrm{~kg}_{\text {grain }} \mathrm{kg}^{-1} \mathrm{~N}\right)$. Irrespective of locations, the conjoint use of $\mathrm{N}$ with $\mathrm{K}$ increases the $\mathrm{PFP}_{\mathrm{n}}$ in both the crops in RWCS over the $\mathrm{N}$ alone. However, the maximum increase in $\mathrm{PFP}_{\mathrm{n}}$ due to combined application of $\mathrm{N}$ with $\mathrm{K}$ over $\mathrm{N}$ alone was recorded at Nainital $(18 \%)$ in the case of rice and at Samba (20\%) in the case of wheat. $\mathrm{PFP}_{\mathrm{n}}$ was further increased over the $\mathrm{N}$ alone, when $\mathrm{N}$ applied with $\mathrm{P}$ and $\mathrm{K}$ together in both the crops. The average of $\mathrm{PFP}_{\mathrm{n}}$ across locations showed that the combined use of $\mathrm{N}$ with $\mathrm{P}$ and $\mathrm{K}$ resulted in $45 \mathrm{~kg}$ grain $\mathrm{kg}^{-1}$ $\mathrm{N}$ in rice and $33 \mathrm{~kg}$ grain $\mathrm{kg}^{-1} \mathrm{~N}$ in wheat. The maximum increment in $\mathrm{PFP}_{\mathrm{n}}$ of rice was registered at Katni $(49 \%)$ and in wheat at Pakur $(50 \%)$ over $\mathrm{N}$ alone. The minimum improvement in $\mathrm{PFP}_{\mathrm{n}}$ due 
to combined use of these the nutrients was noted at Amritsar in both rice and wheat over $\mathrm{N}$ alone. Improvement in $\mathrm{PFP}_{\mathrm{n}}$ over the remaining fertilizer combinations was also noted in both the crops across the locations where application of NPK was combined with Zn. Across locations, application of $\mathrm{NPK}+\mathrm{Zn}$ increases $\mathrm{PFP}_{\mathrm{n}}$ approximately $66 \%$ and $67 \%$ in rice and wheat over $\mathrm{N}$ alone, respectively.

Different combinations of NP and $\mathrm{K}$ influence the $\mathrm{PFP}_{\mathrm{p}}$ in both the crops across the locations. FFMP recorded the maximum mean value of $\mathrm{PFP}_{\mathrm{p}}$ in both the crops (Table 4). Combined application of $\mathrm{P}$ with $\mathrm{N}$ recorded the mean value of $71 \mathrm{~kg}_{\text {grain }} \mathrm{kg}^{-1} \mathrm{P}$ in rice and $54 \mathrm{~kg}$ grain kg-1 $\mathrm{P}$ in wheat. However, $\mathrm{PFP}_{\mathrm{p}}$ of applied $\mathrm{P}$ with $\mathrm{N}$ varied from $45 \mathrm{~kg}$ grain $\mathrm{kg}^{-1} \mathrm{P}$ (Amritsar) to $113 \mathrm{~kg}$ grain $\mathrm{kg}^{-1} \mathrm{P}$ (Samba) in rice and $5 \mathrm{~kg}_{\text {grain }} \mathrm{kg}^{-1} \mathrm{P}$ (Kanpur) to $69 \mathrm{~kg}$ grain $\mathrm{kg}^{-1}$ of $\mathrm{P}$ (Nainital) in wheat. A reasonable difference was noted in $\mathrm{PFP}_{\mathrm{p}}$ when $\mathrm{P}$ application was combined with $\mathrm{N}$ and $\mathrm{K}$ in both the crops at all locations. The mean of all the locations summarized that $\mathrm{PFP}_{\mathrm{p}}$ of $\mathrm{NPK}$ application both in rice and wheat was increased $20 \%$ over the combined application of $\mathrm{N}$ and P, respectively. The minimum and maximum improvements in $\mathrm{PFP}_{\mathrm{p}}$ of both the crops over $\mathrm{N}$ and $\mathrm{P}$ application were noted at Amritsar and Katni, respectively. Application of Zn with NPK further increases the PFP of both rice and wheat over rest of the fertilizer treatments. However, $\mathrm{PFP}_{\mathrm{p}}$ of $\mathrm{NPK}+\mathrm{Zn}$ in rice was varied between the locations and ranged from $54 \mathrm{~kg}_{\text {grain }} \mathrm{kg}^{-1} \mathrm{P}$ at Amritsar to $137 \mathrm{~kg}$ grain kg-1 $\mathrm{P}$ at Samba, although maximum per cent increase in $\mathrm{PFP}_{\mathrm{p}}$ of rice due to $\mathrm{Zn}$ application along with NPK was noted at Katni (11\%) over the combined application of NP and K. Similarly, in wheat PFP of NPK+ Zn ranged from $36 \mathrm{~kg}_{\text {grain }} \mathrm{kg}^{-1} \mathrm{P}$ at Amritsar to $103 \mathrm{~kg}$ grain kg ${ }^{-1} \mathrm{P}$ at Katni. However, the maximum enhancement in PFP $_{p}$ of applied NPK+Zn over NP in wheat was observed at Amritsar $(16 \%)$ and minimum at Pakur (15\%). Irrespective of locations, $\mathrm{Zn}$ application recorded the higher values of $\mathrm{PFP}_{\mathrm{p}}$ over other fertilizer treatments in wheat.

$\mathrm{PFP}_{\mathrm{k}}$ for applied $\mathrm{K}$ with $\mathrm{N}$ when averaged over the location was $85 \mathrm{~kg}_{\text {grain }} \mathrm{kg}^{-1} \mathrm{~K}$ in rice and $86 \mathrm{~kg}$ grain $\mathrm{kg}^{-1} \mathrm{~K}$ in wheat (Table 4). $\mathrm{PFP}_{\mathrm{k}}$ in rice however, ranged from $29 \mathrm{~kg}$ grain kg${ }^{-1} \mathrm{~K}$ in Nainital to $199 \mathrm{~kg}$ grain $\mathrm{kg}^{-1} \mathrm{~K}$ in Samba. In wheat, $\mathrm{PFP}_{\mathrm{k}}$ ranged from $25 \mathrm{~kg}_{\text {grain kg }}{ }^{-1} \mathrm{~K}$ in Nainital to $139 \mathrm{~kg}$ grain $\mathrm{kg}^{-1} \mathrm{~K}$ in Katni. The combined application of $\mathrm{NP}$ and $\mathrm{K}$ increase the $\mathrm{PFP}_{\mathrm{k}}$ for applied $\mathrm{K}$ at all the location. Response of combined application of $\mathrm{K}$ along with $\mathrm{N}$ and $\mathrm{P}$ when averaged over the location was $114 \%$ in rice and $93 \%$ in wheat over $\mathrm{N}$ and $\mathrm{K}$ application. However, the response of applied $\mathrm{K}$ along with $\mathrm{N}$ and $\mathrm{P}$ in rice ranged from $19 \%$ at Ambedkarnagar to $45 \%$ at Katni over $\mathrm{N}$ and $\mathrm{K}$ application. In wheat, the increment in $\mathrm{PFP}_{\mathrm{k}}$ ranged from $5 \%$ at Dindori and $92 \%$ at Samba over the $\mathrm{N}$ and $\mathrm{K}$ application. Inclusion of $\mathrm{Zn}$ marginally reduces the $\mathrm{PFP}_{\mathrm{k}}$ at all locations in both the crops. The response of applied $\mathrm{Zn}$ when averaged over the location was negative in both the crops over NP and $\mathrm{K}$ application. However, the mean reduction in $\mathrm{PFP}_{\mathrm{k}}$ of wheat $(31 \%)$ was more than in rice $(6 \%)$. Although, $\mathrm{PFP}_{\mathrm{k}}$ of applied $\mathrm{K}$ with NPK and $\mathrm{Zn}$ was remains greater than the $\mathrm{N}$ and $\mathrm{K}$ application in both the crops at all the locations (Table 4). 
Table 4. Partial Factor Productivity (PFP) of N, P, and $\mathrm{K}\left(\mathrm{kg}_{\text {grain }} \mathrm{kg}^{-1}\right.$ nutrient applied) of rice and wheat in RWCS across the locations in India.

\begin{tabular}{|c|c|c|c|c|c|c|c|c|c|c|c|c|}
\hline Location & & & & Rice & & & & & & Wheat & & \\
\hline \multicolumn{13}{|c|}{ Partial Factor Productivity of N $\left(\mathrm{PFP}_{n}\right)$} \\
\hline & $\mathrm{N}$ alone & With P & With K & With PK & With PK and Mn & FFMP & $\mathrm{N}$ alone & With P & With K & With PK & With PK and Zn & FFMP \\
\hline Amritsar & $41 \pm 1.15$ & $46 \pm 1.08$ & $43 \pm 1.17$ & $49 \pm 1.24$ & $54 \pm 1.3$ & $41 \pm 1.0$ & $28.75 \pm 1.08$ & $32 \pm 1.11$ & $31 \pm 0.93$ & $36 \pm 1.00$ & $38 \pm 1.05$ & $29 \pm 0.76$ \\
\hline Katni & $25 \pm 0.42$ & $33 \pm 0.45$ & $27 \pm 0.58$ & $50 \pm 0.66$ & $56 \pm 0.60$ & $45 \pm 0.47$ & $23.50 \pm 0.43$ & $32 \pm 0.35$ & $25 \pm 0.31$ & $46 \pm 0.46$ & $51 \pm 0.36$ & $44 \pm 0.70$ \\
\hline Nainital & $24 \pm 0.48$ & $32 \pm 0.79$ & $29 \pm 0.80$ & $37 \pm 0.65$ & $38 \pm 0.50$ & $39 \pm 0.58$ & $22.12 \pm 0.59$ & $28 \pm 0.64$ & $25 \pm 0.66$ & $33 \pm 0.54$ & $34 \pm 0.51$ & $36 \pm 1.21$ \\
\hline Samba & $55 \pm 1.53$ & $75 \pm 1.44$ & $66 \pm 1.32$ & $89 \pm 1.78$ & $92 \pm 1.72$ & $109 \pm 1.43$ & $16.33 \pm 0.72$ & $24 \pm 0.66$ & $21 \pm 0.60$ & $28 \pm 0.71$ & $29 \pm 0.75$ & $44 \pm 1.11$ \\
\hline Pakur & $19 \pm 0.22$ & $29 \pm 0.28$ & $22 \pm 0.29$ & $35 \pm 0.31$ & $36 \pm 0.38$ & $37 \pm 0.89$ & $16.45 \pm 0.21$ & $29 \pm 0.22$ & $19 \pm 0.20$ & $33 \pm 0.22$ & $34 \pm 0.24$ & $34 \pm 0.63$ \\
\hline Kanpur & $22 \pm 0.19$ & $33 \pm 0.28$ & $26 \pm 0.52$ & $36 \pm 0.32$ & $39 \pm 0.35$ & $19 \pm 0.37$ & $20.29 \pm 0.11$ & $27 \pm 0.06$ & $23 \pm 0.41$ & $31 \pm 0.11$ & $33 \pm 0.13$ & $26 \pm 0.09$ \\
\hline Ambedkarnagar & $21 \pm 0.44$ & $26 \pm 0.54$ & $23 \pm 0.52$ & $29 \pm 0.67$ & $31 \pm 0.65$ & $30 \pm 0.55$ & $15.05 \pm 0.48$ & $19 \pm 0.57$ & $17 \pm 0.59$ & $22 \pm 0.58$ & $23 \pm 0.59$ & $23 \pm 0.71$ \\
\hline Dindori & $22 \pm 0.53$ & $29 \pm 0.82$ & $27 \pm 0.71$ & $33 \pm 0.73$ & & $57 \pm 1.31$ & $23.50 \pm 0.62$ & $29 \pm 0.57$ & $28 \pm 0.72$ & $35 \pm 0.68$ & $37 \pm 0.86$ & $51 \pm 1.55$ \\
\hline Mean & 29 & 38 & 33 & 45 & 48 & 47 & 21 & 27 & 24 & 33 & 35 & 36 \\
\hline \multicolumn{13}{|c|}{ Partial Factor Productivity of $\mathrm{P}\left(\mathrm{PFP}_{\mathrm{p}}\right)$} \\
\hline & & With $\mathrm{N}$ & & With NK & With NK and Zn & FFMP & & With $\mathrm{N}$ & & With NK & With NK and Zn & FFMP \\
\hline Amritsar & - & $45 \pm 1.08$ & - & $49 \pm 1.24$ & $54 \pm 1.30$ & $40 \pm 1.00$ & - & $32 \pm 1.11$ & - & $36 \pm 1.00$ & $38 \pm 1.05$ & $29 \pm 0.67$ \\
\hline Katni & - & $65 \pm 0.88$ & - & $99 \pm 1.33$ & $110 \pm 1.22$ & $119 \pm 1.20$ & - & $63 \pm 0.73$ & - & $92 \pm 0.92$ & $103 \pm 0.69$ & $117 \pm 1.84$ \\
\hline Nainital & - & $81 \pm 1.95$ & - & $93 \pm 1.59$ & $96 \pm 1.28$ & $65 \pm 0.96$ & - & $69 \pm 1.60$ & - & $82 \pm 1.36$ & $86 \pm 1.31$ & $90 \pm 3.01$ \\
\hline Samba & - & $113 \pm 2.17$ & - & $133 \pm 2.63$ & $137 \pm 2.60$ & $218 \pm 2.86$ & - & $47 \pm 1.33$ & - & $56 \pm 1.46$ & $58 \pm 1.47$ & $111 \pm 2.73$ \\
\hline Pakur & - & $59 \pm 0.58$ & - & $69 \pm 0.63$ & $71 \pm 0.79$ & $44 \pm 1.09$ & - & $57 \pm 0.47$ & - & $66 \pm 0.43$ & $68 \pm 0.44$ & $40 \pm 0.74$ \\
\hline Kanpur & - & $82 \pm 0.67$ & - & $91 \pm 0.75$ & $97 \pm 0.92$ & $64 \pm 1.22$ & - & $5 \pm 0.13$ & - & $62 \pm 0.25$ & $65 \pm 0.26$ & $55 \pm 0.15$ \\
\hline Ambedkarnagar & - & $67 \pm 1.35$ & - & $73 \pm 1.64$ & $78 \pm 1.63$ & $100 \pm 2.20$ & - & $49 \pm 1.40$ & - & $55 \pm 1.45$ & $58 \pm 1.44$ & $93 \pm 2.81$ \\
\hline Dindori & - & $59 \pm 1.61$ & - & $67 \pm 1.41$ & $75 \pm 2.18$ & $123 \pm 2.87$ & - & $57 \pm 1.20$ & - & $69 \pm 1.33$ & $73 \pm 1.68$ & $132 \pm 4.08$ \\
\hline Mean & & 71 & & 85 & 90 & 99 & & 54 & & 65 & 69 & 83 \\
\hline \multicolumn{13}{|c|}{ Partial Factor Productivity of $\mathrm{K}\left(\mathrm{PFP}_{\mathrm{k}}\right)$} \\
\hline & & & With $\mathrm{N}$ & With NP & With NP and Zn & & & & With $\mathrm{N}$ & With NP & With NP and Zn & \\
\hline Amritsar & - & - & $43 \pm 1.17$ & $49 \pm 1.24$ & $54 \pm 1.30$ & - & - & - & $31 \pm 0.93$ & $36 \pm 1.00$ & $38 \pm 1.05$ & - \\
\hline Katni & - & - & $82 \pm 1.77$ & $149 \pm 1.98$ & $166 \pm 1.84$ & - & - & - & $139 \pm 1.30$ & $154 \pm 1.10$ & $88 \pm 1.39$ & - \\
\hline Nainital & - & - & $29 \pm 0.80$ & $37 \pm 0.65$ & $38 \pm 0.50$ & - & - & - & $25 \pm 0.66$ & $33 \pm 0.54$ & $34 \pm 0.51$ & - \\
\hline Samba & - & - & $199 \pm 4.06$ & $266 \pm 5.39$ & $274 \pm 5.30$ & - & - & - & $112 \pm 2.92$ & $145 \pm 37.01$ & $88 \pm 2.20$ & - \\
\hline Pakur & - & - & $87 \pm 1.07$ & $100 \pm 1.24$ & $100 \pm 1.58$ & - & - & - & $100 \pm 0.86$ & $100 \pm 0.93$ & $81 \pm 1.48$ & - \\
\hline Kanpur & - & - & $98 \pm 1.88$ & $135 \pm 1.15$ & $39 \pm 0.35$ & - & - & - & $93 \pm 0.35$ & $98 \pm 0.38$ & $83 \pm 0.22$ & - \\
\hline Ambedkarnagar & - & - & $58 \pm 1.29$ & $73 \pm 1.64$ & $78 \pm 1.63$ & - & - & - & $82 \pm 2.17$ & $87 \pm 2.16$ & $69 \pm 2.11$ & - \\
\hline Dindori & - & - & $81 \pm 2.20$ & $100 \pm 2.09$ & $112 \pm 3.29$ & - & - & - & $104 \pm 1.97$ & $110 \pm 2.52$ & $76 \pm 2.35$ & - \\
\hline Mean & & & 85 & 114 & 108 & & & & 86 & 93 & 69.70 & \\
\hline
\end{tabular}




\subsection{Effect of NPK and Zn on AUE of RWCS}

In our study, irrespective of fertilizer treatments, the agronomic use efficiency of applied $N\left(A_{U} E_{n}\right)$ is greater in rice than in wheat at all locations (Table 5). The $\mathrm{AUE}_{\mathrm{n}}$ of $\mathrm{N}$ alone when averaged over the locations was $9.8 \mathrm{~kg}_{\text {grain }} \mathrm{kg}^{-1} \mathrm{~N}$ in rice and $7.8 \mathrm{~kg}_{\text {grain }} \mathrm{kg}^{-1} \mathrm{~N}$ in wheat. However, $\mathrm{AUE}_{\mathrm{n}}$ of $\mathrm{N}$ alone in rice ranged from $5 \mathrm{~kg}$ grain $\mathrm{kg} \mathrm{N}$ in Nainital to $16 \mathrm{~kg}$ grain $\mathrm{kg}$ of $\mathrm{N}$ in Amritsar. Similarly in wheat, $\mathrm{AUE}_{\mathrm{n}}$ of $\mathrm{N}$ alone ranged from $3 \mathrm{~kg}$ grain $\mathrm{kg}^{-1} \mathrm{~N}$ in Kanpur to $12 \mathrm{~kg}_{\text {grain }} \mathrm{kg}^{-1} \mathrm{~N}$ in Samba. AUE increases at all the locations in both the crops, when $\mathrm{N}$ was supplied along with P. Mean of all the locations showed that when $N$ was applied with $P$ the $A U E_{n}$ was increases in the tune of $99 \%$ in rice and $108 \%$ in wheat over $\mathrm{N}$ alone. The $\mathrm{AUE}_{n}$ was also higher when $\mathrm{N}$ was supplied with $\mathrm{K}$ than the $\mathrm{N}$ alone. When $\mathrm{AUE}_{n}$ of applied $\mathrm{N}$ with $\mathrm{K}$ averaged across the locations was $14.4 \mathrm{~kg}_{\text {grain }} \mathrm{kg}^{-1} \mathrm{~N}$ in rice and $12.1 \mathrm{~kg}_{\text {grain }} \mathrm{kg}^{-1} \mathrm{~N}$. AUE $\mathrm{n}_{\mathrm{n}}$ was further increased when $\mathrm{N}$ was applied in combination with $\mathrm{P}$ and $\mathrm{K}$ over $\mathrm{N}$ alone in both the crops. However, when the response of $\mathrm{N}$ with $\mathrm{P}$ in terms of $\mathrm{AUE}_{\mathrm{n}}$ averaged over the location the increment in $\mathrm{AUE}_{n}$ was $168 \%$ in rice and $206 \%$ in wheat over $\mathrm{N}$ alone. Application of $\mathrm{Zn}$ along with balance application of NPK augments the AUE $\mathrm{n}$ in both the crops in all the locations. When $\mathrm{AUE}_{n}$ averaged over the locations, $\mathrm{Zn}$ contributed $6 \%$ and $17 \%$ enhancement in $\mathrm{AUE}_{n}$ of rice and wheat over NPK, respectively.

Agronomic use efficiency of applied $\mathrm{P}\left(\mathrm{AUE}_{\mathrm{p}}\right)$ along with $\mathrm{N}$ was higher in rice than in wheat at all the locations. In rice, $\mathrm{AUE}_{\mathrm{p}}$ ranged from $26 \mathrm{~kg}$ grain $\mathrm{kg} P$ in Dindori to $83 \mathrm{~kg}$ grain $\mathrm{kg} P$ in Amritsar.

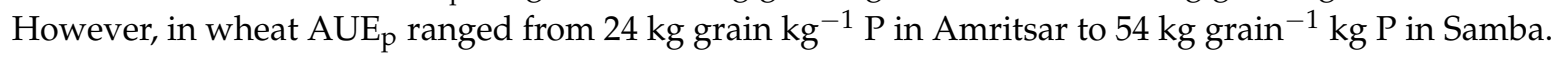
The AUE $\mathrm{p}_{\mathrm{p}}$ increases in both the crops when $\mathrm{P}$ fertilizer assigned with $\mathrm{N}$ and $\mathrm{K}$ in both the crops over $\mathrm{N}$ and $\mathrm{P}$ application. In rice the $\mathrm{AUE}_{\mathrm{p}}$ ranged from $8 \mathrm{~kg}$ grain $\mathrm{kg} P$ in Dindori to $98 \mathrm{~kg}$ grain $\mathrm{kg} P$ in Amritsar. Similarly, in wheat $\mathrm{AUE}_{\mathrm{p}}$ ranged from $7 \mathrm{~kg}_{\text {grain }}{ }^{-1} \mathrm{~kg} \mathrm{P}$ in Amritsar to $64 \mathrm{~kg}$ grain $^{-1} \mathrm{~kg} \mathrm{P}$ in Katni. On an average across the locations, the applications of NPK along with Zn further augment the $\mathrm{AUE}_{\mathrm{p}}$ of rice by $34 \%$ and by $47 \%$ of wheat over the NP and $\mathrm{K}$ application.

In general, AUE of applied $\mathrm{K}\left(\mathrm{AUE}_{\mathrm{k}}\right)$ was greater in rice than in wheat in all the fertilizers treatment across the locations. When $\mathrm{AUE}_{\mathrm{k}}$ along with $\mathrm{N}$ averaged over the locations, in rice it ranged between $6 \mathrm{~kg}_{\text {grain }}{ }^{-1} \mathrm{~kg} \mathrm{~K}$ in Ambedkarnagar to $52 \mathrm{~kg}_{\text {grain }}{ }^{-1} \mathrm{~kg} \mathrm{~K}$ in Pakur, whereas in wheat the $\mathrm{AUE}_{\mathrm{k}}$ with $\mathrm{N}$ ranged from $8 \mathrm{~kg}$ grain ${ }^{-1} \mathrm{~kg} \mathrm{~K}$ in Ambedkarnagar to $50 \mathrm{~kg}_{\text {grain }}{ }^{-1} \mathrm{~kg} \mathrm{~K}$ in Pakur. Averaged of all the location indicates that the application of $K$ with NP increases the $\mathrm{AUE}_{\mathrm{k}}$ in the tune of $59 \%$ in rice and $56 \%$ in wheat over $\mathrm{N}$ and $\mathrm{K}$ application. Application of $\mathrm{Zn}$ along with NPK attributed positive effect on $\mathrm{AUE}_{\mathrm{k}}$ in both the crops at all the locations. Across the locations $18 \%$ and $16 \%$ increment in $\mathrm{AUE}_{\mathrm{k}}$ was noticed in rice and wheat over NP and $\mathrm{K}$ application, respectively. 
Table 5. Agronomic use efficiency (AUE) of N, P, and $\mathrm{K}$ ( $\mathrm{kg}$ increased grain yield $\mathrm{kg}^{-1}$ nutrient applied) of rice and wheat in RWCS across the locations in India.

\begin{tabular}{|c|c|c|c|c|c|c|c|c|c|c|c|c|}
\hline Location & \multicolumn{5}{|c|}{ Rice } & & \multicolumn{6}{|c|}{ Wheat } \\
\hline \multicolumn{13}{|c|}{$A U E_{n}$} \\
\hline & $\mathrm{N}$ alone & With $\mathrm{P}$ & With K & With PK & With PK and Zn & FFMP & $\mathrm{N}$ alone & With $\mathrm{P}$ & With K & With PK & With PK and Zn & FFMP \\
\hline Amritsar & $16 \pm 1.24$ & $21 \pm 1.34$ & $18 \pm 1.19$ & $25 \pm 1.68$ & $29 \pm 1.57$ & $20 \pm 1.34$ & $8 \pm 1.05$ & $12 \pm 1.04$ & $10 \pm 0.89$ & $16 \pm 1.02$ & $18 \pm 1.12$ & $13 \pm 0.91$ \\
\hline Katni & $11 \pm 0.44$ & $19 \pm 0.55$ & $13 \pm 0.68$ & $36 \pm 0.60$ & $41 \pm 0.70$ & $24 \pm 0.66$ & $9 \pm 0.51$ & $17 \pm 0.53$ & $11 \pm 0.55$ & $32 \pm 0.56$ & $37 \pm 0.34$ & $23 \pm 0.95$ \\
\hline Nainital & $5 \pm 0.49$ & $14 \pm 0.60$ & $11 \pm 0.59$ & $19 \pm 0.52$ & $10 \pm 0.55$ & $11 \pm 1.08$ & $6 \pm 0.35$ & $11 \pm 0.54$ & $9 \pm 0.51$ & $16 \pm 0.67$ & $18 \pm 0.66$ & $12 \pm 1.06$ \\
\hline Samba & $14 \pm 0.70$ & $34 \pm 0.60$ & $25 \pm 0.87$ & $47 \pm 1.30$ & $50 \pm 1.17$ & $47 \pm 2.48$ & $12 \pm 2.48$ & $36 \pm 1.70$ & $26 \pm 1.43$ & $52 \pm 1.88$ & $55 \pm 1.84$ & $47 \pm 2.51$ \\
\hline Pakur & $10 \pm 0.23$ & $21 \pm 0.33$ & $13 \pm 0.30$ & $26 \pm 0.37$ & $27 \pm 0.50$ & $22 \pm 1.03$ & $9 \pm 0.20$ & $21 \pm 0.28$ & $12 \pm 0.20$ & $26 \pm 0.25$ & $27 \pm 0.27$ & $22 \pm 0.70$ \\
\hline Kanpur & $6 \pm 0.20$ & $17 \pm 0.30$ & $11 \pm 0.45$ & $21 \pm 0.21$ & $24 \pm 0.26$ & $8 \pm 0.42$ & $3 \pm 0.04$ & $8 \pm 0.06$ & $6 \pm 0.28$ & $11 \pm 0.07$ & $26 \pm 0.06$ & $6 \pm 0.04$ \\
\hline Ambedkarnagar & $10 \pm 0.26$ & $16 \pm 0.31$ & $13 \pm 0.29$ & $18 \pm 0.44$ & $20 \pm 0.50$ & $17 \pm 0.33$ & $7 \pm 0.30$ & $12 \pm 0.39$ & $10 \pm 0.43$ & $14 \pm 0.41$ & $16 \pm 0.40$ & $14 \pm 0.50$ \\
\hline Dindori & $6 \pm 0.72$ & $13 \pm 0.94$ & $11 \pm 0.91$ & $17 \pm 0.69$ & $21 \pm 1.20$ & $6 \pm 0.69$ & $8 \pm 0.46$ & $13 \pm 0.81$ & $13 \pm 0.96$ & $20 \pm 0.86$ & $21 \pm 0.72$ & $8 \pm 0.84$ \\
\hline Mean & 9.97 & 19.37 & 14.37 & 26.12 & 27.75 & 19.37 & 7.75 & 16.25 & 12.12 & 23.37 & 27.25 & 18.12 \\
\hline \multicolumn{13}{|c|}{$A U E_{p}$} \\
\hline & & With $\mathrm{N}$ & & With NK & With NK and Zn & FFM & & With $\mathrm{N}$ & & With K & With NK and Zn & FFM \\
\hline Amritsar & - & $83 \pm 5.41$ & - & $98 \pm 6.76$ & $115 \pm 6.29$ & $102 \pm 6.74$ & - & $24 \pm 2.09$ & - & $7 \pm 1.87$ & $16 \pm 1.80$ & $65 \pm 4.56$ \\
\hline Katni & - & $37 \pm 1.10$ & - & $72 \pm 1.20$ & $83 \pm 1.40$ & $63 \pm 1.75$ & - & $35 \pm 1.05$ & - & $64 \pm 1.13$ & $74 \pm 0.68$ & $61 \pm 2.54$ \\
\hline Nainital & - & $33 \pm 1.51$ & - & $47 \pm 1.30$ & $49 \pm 1.37$ & $19 \pm 1.80$ & - & $26 \pm 1.35$ & - & $41 \pm 1.69$ & $45 \pm 1.66$ & $29 \pm 2.66$ \\
\hline Samba & - & $50 \pm 0.89$ & - & $20 \pm 1.51$ & $75 \pm 1.75$ & $93 \pm 4.96$ & - & $54 \pm 2.56$ & - & $24 \pm 1.72$ & $82 \pm 2.75$ & $95 \pm 5.02$ \\
\hline Pakur & - & $41 \pm 0.66$ & - & $52 \pm 0.74$ & $54 \pm 0.92$ & $44 \pm 2.05$ & - & $43 \pm 0.56$ & - & $52 \pm 0.50$ & $54 \pm 0.54$ & $44 \pm 1.41$ \\
\hline Kanpur & - & $43 \pm 0.72$ & - & $52 \pm 0.54$ & $59 \pm 0.64$ & $27 \pm 1.13$ & - & $20 \pm 0.15$ & - & $26 \pm 0.17$ & $32 \pm 0.16$ & $32 \pm 0.20$ \\
\hline Ambedkarnagar & - & $39 \pm 0.78$ & - & $46 \pm 1.11$ & $51 \pm 1.27$ & $67 \pm 1.36$ & - & $30 \pm 0.98$ & - & $36 \pm 1.03$ & $39 \pm 1.01$ & $56 \pm 2.03$ \\
\hline Dindori & - & $26 \pm 1.88$ & - & $8 \pm 1.45$ & $42 \pm 2.41$ & $36 \pm 4.54$ & - & $26 \pm 1.63$ & - & $12 \pm 1.44$ & $42 \pm 1.45$ & $50 \pm 5.50$ \\
\hline Mean & - & 44.0 & - & 49.37 & 66.0 & 56.37 & & 32.25 & & 32.75 & 48 & 54 \\
\hline \multicolumn{13}{|c|}{$A U E_{k}$} \\
\hline & & & With $\mathrm{N}$ & With NP & With NP and Zn & & & & With $\mathrm{N}$ & With NP & With NP and Zn & \\
\hline Amritsar & - & - & $8 \pm 3.59$ & $15 \pm 4.54$ & $42 \pm 6.1$ & - & - & - & $8 \pm 3.58$ & $14 \pm 3.74$ & $32 \pm 3.60$ & - \\
\hline Katni & - & - & $40 \pm 2.04$ & $108 \pm 1.81$ & $124 \pm 2.11$ & - & - & - & $34 \pm 1.65$ & $97 \pm 1.70$ & $112 \pm 1.03$ & - \\
\hline Nainital & - & - & $27 \pm 1.48$ & $47 \pm 1.30$ & $49 \pm 1.37$ & - & - & - & $34 \pm 1.90$ & $62 \pm 2.53$ & $68 \pm 2.50$ & - \\
\hline Samba & - & - & $30 \pm 1.04$ & $57 \pm 1.56$ & $60 \pm 1.40$ & - & - & - & $31 \pm 1.72$ & $62 \pm 2.25$ & $65 \pm 2.20$ & - \\
\hline Pakur & - & - & $52 \pm 1.15$ & $103 \pm 1.48$ & $107 \pm 1.85$ & - & - & - & $50 \pm 0.80$ & $104 \pm 1.01$ & $107 \pm 1.09$ & - \\
\hline Kanpur & - & - & $40 \pm 1.71$ & $78 \pm 0.61$ & $88 \pm 0.96$ & - & - & - & $21 \pm 1.06$ & $42 \pm 0.26$ & $47 \pm 0.25$ & - \\
\hline Ambedkarnagar & - & - & $6 \pm 0.47$ & $7 \pm 0.61$ & $19 \pm 0.82$ & - & - & - & $8 \pm 0.97$ & $9 \pm 0.45$ & $23 \pm 0.58$ & - \\
\hline Dindori & - & - & $32 \pm 2.74$ & $51 \pm 2.10$ & $62 \pm 3.62$ & - & - & _- & $38 \pm 2.90$ & $57 \pm 2.60$ & $63 \pm 2.18$ & - \\
\hline Mean & - & - & 29.37 & 58.25 & 68.87 & & & & 28 & 55.87 & 64.62 & \\
\hline
\end{tabular}




\subsection{Relationship of Available OC and NPK with the Productivity of Rice and Wheat in RWCS}

Grain yield of rice and wheat in control plots $\left(\mathrm{Y}_{0}\right)$ was influenced significantly by native available $\mathrm{N}$ and $\mathrm{P}$ content in soil as indicated by highly significant positive correlation coefficients (Figure 3 ). However, grain yield of both rice and wheat was not associated with OC (\%) and native available K. The linear regression was very strong for available $P\left(R^{2}=0.648\right.$ and 0.623 for rice and wheat, respectively) and weak for available $\mathrm{N}\left(\left(\mathrm{R}^{2}=0.417\right.\right.$ and 0.506 for rice and wheat, respectively). Other two inherent soil fertility parameters i.e., OC (\%) and available $\mathrm{K}$, have failed to affect the grain yield of both rice and wheat (Figure 3). Amongst the four intrinsic soil fertility parameters calculated in this study, grain yield of both rice as well as wheat under control plots were found to be governed by only two parameters as described below. The conjoint contribution of available $\mathrm{N}$ and $\mathrm{P}$ contents in determination of grain yield of rice and wheat was $73 \%$ and $75 \%$, respectively.

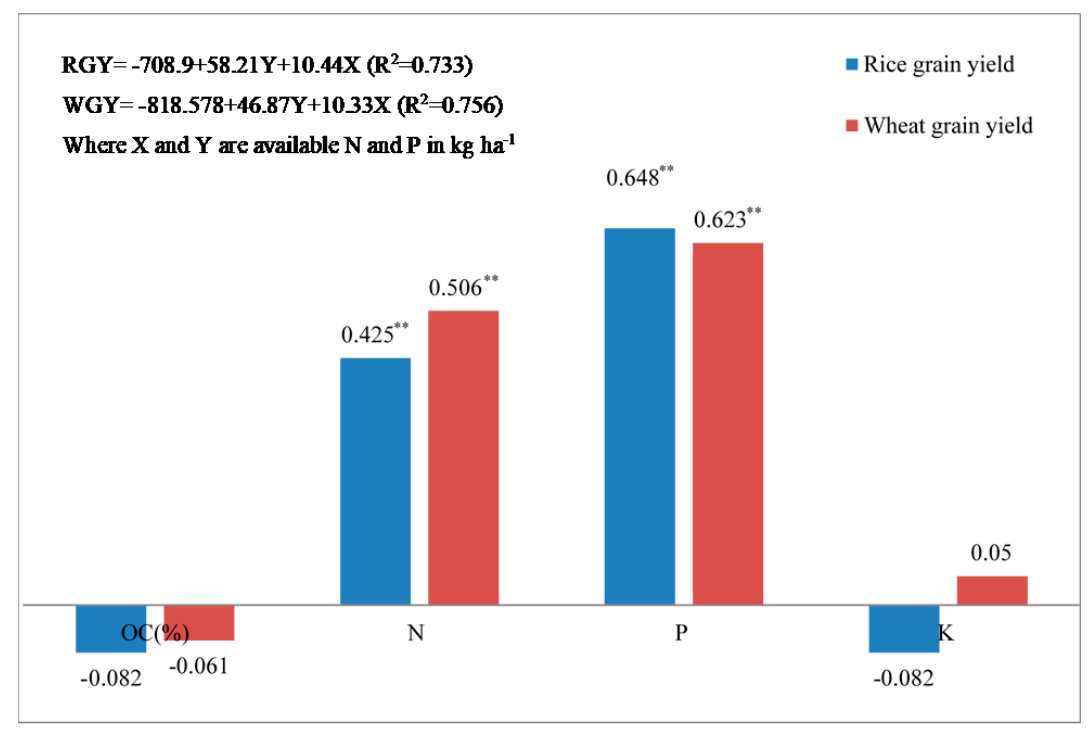

Figure 3. Correlation coefficients (r) of OC (\%) and available $\mathrm{N}, \mathrm{P}$ and $\mathrm{K}\left(\mathrm{kg} \mathrm{ha}^{-1}\right)$ with rice and grain yield at various locations in India. ${ }^{* *}$ means Correlation coefficient significant at $\mathrm{P}=0.01$ level.

\subsection{Financial Budgeting}

The average cost of added fertilizer across the locations for RWCS was INR $4.8 \times 10^{3} \mathrm{ha}^{-1}$ for N, INR $5.3 \times 10^{3} \mathrm{ha}^{-1}$ for P, INR $2.0 \times 10^{3} \mathrm{ha}^{-1}$ for K, and INR $3.0 \times 10^{3} \mathrm{ha}^{-1}$ for Zn. Added fertilizer input cost for systems was small compared to the value of the increased gross return i.e., INR $34.9 \times 10^{3} \mathrm{ha}^{-1}$ for N, INR $31.5 \times 10^{3} \mathrm{ha}^{-1}$ for P, INR $15.0 \times 10^{3} \mathrm{ha}^{-1}$ for K, and INR $10.3 \times 10^{3} \mathrm{ha}^{-1}$ for Zn from the same combinations of fertilizer application (Table 6). Added mean net monetary return for RWCS was lowest (INR $29.5 \times 10^{3} \mathrm{ha}^{-1}$ ) for application of $\mathrm{N}$ alone and the highest (INR $8.65 \times 10^{3} \mathrm{ha}^{-1}$ ) for application of NPK $+\mathrm{Zn}$ compared to control (Table 7). Among the locations, Katni registered the highest net monetary return (INR $176.6 \times 10^{3} \mathrm{ha}^{-1}$ ) while Pakur registered the lowest net monetary return (INR $63.8 \times 10^{3} \mathrm{ha}^{-1}$ ). The increase in mean net monetary returns from NPK $+\mathrm{Zn}$ over farmer practice was found to be $61 \%$, across the locations while increase in the cost of cultivation due to balanced application was found to be only $11 \%$. The mean data showed that cost of cultivation, gross returns, net returns, and B:C ratio were higher with balanced application of nutrients along with micronutrients over other nutrients management practices including farmers fertilizer management practices at all the locations (Tables 6 and 7). Mean marginal returns (MR) of all the locations were found to be higher (INR 836 per $100 \mathrm{~kg} \mathrm{~N}$ applied) with $\mathrm{N}$ alone compared to combined application of NP, NK, NPK, NPK+Zn, and FFMP (Table 8). Among all the locations, Pakur registered higher marginal return with FFMP (INR 1299 per $100 \mathrm{~kg}$ nutrient applied) whereas, minimum marginal returns was recorded at Dindori with application of $\mathrm{N}$ alone. The order of mean marginal returns 
across the locations was with $\mathrm{N}$ alone $>\mathrm{NK}>\mathrm{FFMP}>\mathrm{NPK}>\mathrm{NP}>\mathrm{NPK}+\mathrm{Zn}$. Although yield gains from added nutrients tended to be lower for wheat than rice, however the added net return remained high for wheat because of higher price of wheat grain as compare to rice and lower fertilizer cost for wheat as $\mathrm{Zn}$ was not applied to wheat at all the locations except at Ambedkarnagar. 
Table 6. Effect of N, P, K, and Zn on cost of cultivation and gross returns of RWCS at farmer's field across the locations in India.

\begin{tabular}{|c|c|c|c|c|c|c|c|c|c|c|c|c|c|c|c|c|}
\hline \multirow[t]{2}{*}{ Location } & \multicolumn{8}{|c|}{ Cost of Cultivation $\left(\mathrm{INR} \times 10^{3}\right)$} & \multicolumn{8}{|c|}{ Gross Returns $\left(\right.$ INR $\left.\times 10^{3}\right)$} \\
\hline & Control & $\mathrm{N}$ & $\mathrm{NP}$ & NK & NPK & NPK Zn & FFM & LSD $(5 \%)$ & Control & $\mathrm{N}$ & $\mathrm{NP}$ & NK & NPK & NPK Zn & FFM & $\operatorname{LSD}(5 \%)$ \\
\hline Amritsar & 72.3 & 75.0 & 78.2 & 76.7 & 79.9 & 83.6 & 79.6 & & 83.1 & 128.8 & 143.7 & 136.1 & 157.4 & 170.3 & 160.3 & 9.31 \\
\hline Katni & 34.0 & 40.8 & 47.7 & 44.9 & 49.6 & 53.4 & 43.7 & 3.16 & 61.5 & 106.3 & 138.8 & 117.0 & 207.6 & 230.0 & 128.6 & 6.97 \\
\hline Nainital & 77.9 & 86.5 & 92.7 & 89.6 & 97.1 & 102.5 & 92.2 & 2.59 & 103.7 & 135.7 & 177.2 & 161.0 & 205.9 & 213.8 & 149.0 & 6.85 \\
\hline Samba & 43.0 & 45.3 & 49.6 & 46.6 & 51.5 & 52.8 & 47.9 & 0.27 & 69.4 & 94.9 & 127.0 & 111.4 & 151.1 & 155.4 & 121.8 & 6.41 \\
\hline Pakur & 44.8 & 48.4 & 53.6 & 49.9 & 55.1 & 57.4 & 48.1 & 0.03 & 27.7 & 60.9 & 100.8 & 71.5 & 117.8 & 121.2 & 73.9 & 2.40 \\
\hline Kanpur & 53.1 & 56.7 & 62.9 & 58.4 & 63.7 & 65.3 & 63.9 & 1.01 & 76.9 & 100.2 & 141.9 & 118.0 & 158.9 & 170.1 & 143.7 & 2.39 \\
\hline Ambedkarnagar & 36.0 & 40.0 & 45.0 & 41.6 & 46.7 & 49.3 & 43.4 & 0.51 & 47.7 & 90.8 & 115 & 101.6 & 127 & 136.4 & 107.8 & 3.48 \\
\hline Dindori & 41.6 & 47.9 & 53.3 & 49.3 & 55.1 & 57.8 & 51.7 & 0.01 & 64.8 & 91.2 & 117.3 & 112.4 & 138.1 & 149.0 & 99.4 & 9.43 \\
\hline Mean & 50.3 & 55.1 & 60.4 & 57.1 & 62.3 & 65.3 & 58.8 & - & 66.9 & 101.1 & 132.7 & 116.1 & 158.0 & 168.3 & 123.1 & - \\
\hline
\end{tabular}

Table 7. Effect of N, P, K, and Zn on net returns and B:C ratio of RWCS at farmer's field across the locations in India.

\begin{tabular}{|c|c|c|c|c|c|c|c|c|c|c|c|c|c|c|c|c|}
\hline \multirow[t]{2}{*}{ Location } & \multicolumn{8}{|c|}{ Net Returns $\left(\right.$ INR $\left.\times 10^{3}\right)$} & \multicolumn{8}{|c|}{ B:C Ratio } \\
\hline & Control & $\mathrm{N}$ & NP & NK & NPK & NPK Zn & FFMP & $\operatorname{LSD}(5 \%)$ & Control & $\mathrm{N}$ & NP & NK & NPK & NPK Zn & FFMP & $\operatorname{LSD}(5 \%)$ \\
\hline Amritsar & 10.8 & 53.7 & 65.4 & 59.4 & 77.5 & 86.6 & 80.4 & 9.31 & 1.14 & 1.71 & 1.83 & 1.77 & 1.96 & 2.03 & 2.01 & 0.12 \\
\hline Katni & 27.5 & 65.5 & 91.1 & 72.1 & 157.9 & 176.6 & 84.9 & 7.28 & 1.81 & 2.60 & 2.90 & 2.60 & 4.28 & 4.30 & 2.94 & 0.44 \\
\hline Nainital & 25.8 & 49.2 & 84.5 & 71.4 & 108.8 & 111.4 & 56.8 & 7.48 & 1.33 & 1.56 & 1.91 & 1.79 & 2.12 & 2.09 & 1.61 & 0.09 \\
\hline Samba & 26.4 & 49.6 & 77.2 & 64.7 & 99.6 & 102.5 & 73.9 & 6.30 & 1.61 & 2.09 & 2.55 & 2.38 & 2.93 & 2.93 & 2.54 & 0.13 \\
\hline Pakur & -17.1 & 12.5 & 47.1 & 21.7 & 62.7 & 63.8 & 25.8 & 2.40 & 0.61 & 1.25 & 1.87 & 1.43 & 2.13 & 2.11 & 1.53 & 0.04 \\
\hline Kanpur & 23.7 & 43.5 & 79.0 & 59.6 & 95.3 & 104.8 & 80.8 & 2.49 & 1.44 & 1.76 & 2.25 & 2.02 & 2.49 & 2.60 & 2.28 & 0.05 \\
\hline Ambedkarnagar & 11.6 & 50.7 & 70.0 & 60.0 & 81.3 & 87.1 & 64.4 & 3.52 & 1.32 & 2.26 & 2.55 & 2.44 & 2.74 & 2.76 & 2.48 & 0.08 \\
\hline Dindori & 23.2 & 43.3 & 64.0 & 63.1 & 82.9 & 91.2 & 47.7 & 9.43 & 1.56 & 1.90 & 2.20 & 2.28 & 2.50 & 2.57 & 1.92 & 0.18 \\
\hline Mean & 16.5 & 46.0 & 72.3 & 59.0 & 95.8 & 103.0 & 64.3 & - & 1.35 & 1.89 & 2.26 & 2.09 & 2.64 & 2.67 & 2.16 & - \\
\hline
\end{tabular}


Table 8. Effect of NPK and Zn on cost of marginal returns of RWCS at farmer's field across the locations in India.

\begin{tabular}{|c|c|c|c|c|c|c|}
\hline \multirow[b]{2}{*}{ Location } & \multirow[b]{2}{*}{$\mathrm{N}$} & \multicolumn{5}{|c|}{ Fertilizer Treatments } \\
\hline & & $\mathrm{NP}$ & NK & NPK & NPK Zn & FFMP \\
\hline Amritsar & $1578.7 \pm 109.50$ & $1103.9 \pm 62.64$ & $916.09 \pm 42.11$ & $872.47 \pm 45.05$ & $665.28 \pm 33.76$ & $945.09 \pm 55.91$ \\
\hline Katni & $561.44 \pm 20.16$ & $406.95 \pm 30.98$ & $463.89 \pm 11.56$ & $462.95 \pm 270.34$ & $766.21 \pm 7.45$ & $729.65 \pm 146.53$ \\
\hline Nainital & $621.81 \pm 243.05$ & $466.84 \pm 57.85$ & $464.18 \pm 50.46$ & $497.49 \pm 45.68$ & $388.47 \pm 32.47$ & $259.16 \pm 37.00$ \\
\hline Samba & $1006.1 \pm 117.97$ & $1047.2 \pm 20.05$ & $750.79 \pm 14.26$ & $858.73 \pm 14.44$ & $772.22 \pm 12.85$ & $977.75 \pm 31.06$ \\
\hline Pakur & $841.39 \pm 15.13$ & $772.04 \pm 10.95$ & $730.15 \pm 8.65$ & $774.68 \pm 6.42$ & $645.01 \pm 64.84$ & $1298.6 \pm 28.57$ \\
\hline Kanpur & $634.43 \pm 57.26$ & $703.65 \pm 38.15$ & $583.55 \pm 20.52$ & $677.3 \pm 11.23$ & $669.8 \pm 12.73$ & $592.21 \pm 20.79$ \\
\hline Ambedkarnagar & $1126.3 \pm 196.16$ & $910.17 \pm 68.69$ & $650.35 \pm 18.83$ & $654.69 \pm 19.12$ & $570.47 \pm 16.78$ & $714.25 \pm 20.89$ \\
\hline Dindori & $319.41 \pm 34.32$ & $521.83 \pm 43.67$ & $348.91 \pm 22.76$ & $442.74 \pm 19.34$ & $419.38 \pm 20.55$ & $244.04 \pm 34.09$ \\
\hline Mean & $794.8 \pm 99.40$ & $741.6 \pm 41.63$ & $613.5 \pm 23.62$ & $655.1 \pm 54.01$ & $612.1 \pm 17.92$ & $720.1 \pm 47.40$ \\
\hline
\end{tabular}




\section{Discussion}

Results of present study showed that, yield of both rice and wheat including SRGEY (system productivity) in RWCS was greater in plots, received N, NP, NPK, NPK+Zn, and FFMP over control (no fertilizer treatment was sorted) at all the locations in India. Among the fertilizer treatments, the highest grain yield of both rice and wheat as well as system productivity was recorded with balance fertilization of NPK and Zn. In the control plot (no fertilizer treatment assigned) the higher grain yield of rice, wheat, and SRGEY was reported at Amritsar, Nainital, Kanpur, and Dindori as compared to Katni, Samba, Ambedkarnagar, and Pakur (Table 4). This difference in grain yield between high productivity region (Amritsar, Nainital, Kanpur, and Dindori) and low productivity region (Katni, Samba, Ambedkarnagar, and Pakur), was principally due to the variation in climatic conditions especially in rainfall, temperature and sunshine hours of the location $[8,43]$, variation in management practices [2], and in sowing and planting windows of rice and wheat (Table 3). Dar et al. [21,43] also reported the difference in productivity of RWCS among the various locations in India mainly due to late sowing of wheat after rice in RWCS. The well-developed irrigation infrastructure and climate suitability for the cultivation of rice and wheat in Amritsar, Nainital, and Kanpur may be the witnessed of higher productivity of RWCS at these locations (Table 1 and Section 2). Low productivity of RWCS in Katni, Samba, Ambedkarnagar, and Pakur were associated with poor irrigation facilities, rainfed condition and delayed transplanting and/or sowing of wheat. Poor yield of rice is associated with limited irrigation supply in northern Indian states and has been reported by many researchers [1,2]. The land distribution in these low productivity regions are very skewed, and farmers having the land tenure system and reluctant to purchase the production inputs especially fertilizers and insecticides may also resulted in poor system productivity [2]. Hence, there is an ample scope to improve the productivity of RWCS in these areas through proper irrigation infrastructure development [44], timely transplanting/sowing of rice and wheat in system $[8,45]$, and proper fertilization. Farmers of the high productivity zone leaves the crop stubbles in the field, which after decomposition contributed in soil fertility build up in these regions. Our study suggested that balance fertilization of NPK along with $\mathrm{Zn}$ is the better option to enhance the productivity of RWCS across the locations. Hence, balance fertilization is indispensible for harvesting the targeted crop yield [46]. However, the response of NPK and Zn was lower in high productivity zone (Amritsar, Kanpur, Nainital, and Dindori) than the lower productivity zones (Katni, Pakur, Samba, and Ambedkarnagar). Thus, it may be inferred that response of applied nutrients (NPK) to rice and wheat decreased when $\mathrm{Y}_{0}$ increased. Hence, $\mathrm{Y}_{0}$ was highly dependent on soil inherent nutrients supplying capacity. In the present investigation, native available $\mathrm{N}$ and $\mathrm{P}$ contributed $73 \%$ and $76 \%$ variation in the $\mathrm{Y}_{0}$ of rice and wheat, respectively, as per the following equations.

Rice grain yield $=-708.9+58.21 \mathrm{a}^{*}($ native phosphorus $)+10.44($ native nitrogen $)-\left(\mathrm{R}^{2}=0.733\right)$

Wheat grain yield $=-818.578+46.87^{*}($ native phosphorus $)+10.33^{*}($ native nitrogen $)-\left(R^{2}=0.756\right)$

PFP and AUE are the basic tools for judging the nutrients use efficiency of any nutrients management practice and to develop environmental sound nutrients management strategies. The PFP is increases by increased fertilizer application, better crop management practices, and by increasing nutrients conversion ratio in plant systems [8]. Proper fertilization and crop management practices led to the conversion of solar energy to produce the economic yield and increased the partial factor productivity [47]. PFP and AUE of N, P, and K were considerably improved when balance fertilization of NPK assorted in a particular plots. This was attributed due to synergistic effect of NP and K on plant growth. Balanced use of NPK helped better utilize native and applied nutrients and enhance nutrient use efficiency. Combined application of NPK increased N recovery up to $76 \%$ over conventional $\mathrm{N}$ and $\mathrm{P}$ application [48]. The $\mathrm{PFP}_{\mathrm{n}}$ and $\mathrm{PFP}_{\mathrm{k}}$ were further improved by $\mathrm{Zn}$ application in both the crops. However, $\mathrm{PFP}_{\mathrm{p}}$ showed the decreasing trends when $\mathrm{P}$ was applied with $\mathrm{Zn}$, as $\mathrm{P}$ and $\mathrm{Zn}$ have antagonist effect on plant growth, which resulted in poor recovery of $\mathrm{P}$ [49]. In this study we 
have found that the PFP of applied P either alone or in combination with $\mathrm{N}$ and $\mathrm{K}$ was considerably higher in rice crop as compared to the wheat crop across the locations having different water regimes in contrary to the earlier reports that rice respond poorly to phosphorus as compared to wheat in RWCS $[7,50]$. This indicates that at farmer's field rice is more responsive to $\mathrm{N}$ and $\mathrm{P}$ application as farmers of the selected locations uses the readily soluble SSP as a source of phosphatic fertilizer. The selected farmer's field was under RWCS from last 10 years at all the locations, which may cause the soil fatigue and degradation. Averaged of all the locations indicates that the application of NPK and $\mathrm{Zn}$ has increased the $\mathrm{AUE}_{\mathrm{n}}$ about $27 \%$ and $50 \%$ in rice and wheat over the FFMP, respectively. Similarly, AUE of P was also higher with $\mathrm{N}$ and K over FFMP in both the crops at all the locations. This was attributed mainly due to suboptimal use of fertilizers especially $\mathrm{P}$ and practically no use of K in RWCS by the farmers. It was elucidated with the data that most of the locations farmers are completely excluded the $\mathrm{K}$ application and applied suboptimal doses of $\mathrm{P}$ and higher doses of $\mathrm{N}$ than their local recommendations. Translocation of photosynthates in the plant system is largely governed by $\mathrm{K}$, which ultimately determines the crop yield [51]. The essentiality of $\mathrm{K}$ for profitable cultivation of RWCS in India was advocated by several researchers [2,52]. Potential of applied nutrients not realized for maintaining the sustainability of production system [53]. The resource poor and unaware farmers of the Indian subcontinent have a tendency to apply $\mathrm{N}$ in the name of fertilizer and not get the proper response. However, there is many fold opportunity to increase the AUE of applied nutrients especially $\mathrm{N}$ when supplied in adequate quantity along with PK and micronutrients across the climatic conditions.

With regards to the financial budgeting/analysis, balance dose of NPK and Zn recorded the significantly higher gross returns, net returns and $\mathrm{B}: \mathrm{C}$ ratio over control. It was also interesting that the cost of cultivation of balance use of NPK and Zn was also higher as compared to the control, but added cost of fertilizers was less as compared to the yield enhancement in both the crops. Irrespective of the fertilizer treatments, among the locations the highest benefit: cost ratio ( $\mathrm{B}: \mathrm{C}$ ratio) of applied fertilizers in RWCS was recorded at Katni. Averaged of B:C ratio across the locations showed that the balance application of NPK and Zn recorded 97.7\% higher B:C ratio over control. However, B:C ratio varied from 2.03 at Amritsar to 4.30 at Katni. Marginal profit analysis showed that across the locations farmers earned additional INR 7.9 invested in N fertilizers over control. Among the fertilizer treatments, application of recommended dose of $\mathrm{N}$ gained more additional income over the others. Farmers earned more income per INR invested with FFMP at all the location except at Dindori, Kanpur and Nainital over NPK and Zn application. This might be due to the poor response of K coupled with the high cost of $K$ fertilizers. Hence, addition of $K$ through fertilizers has not been an economical proposition in RWCS, perhaps due to replenishment of available $\mathrm{K}$ from nonexchangeable pool of soil as it contributes more than $50 \%$ of total K acquisition in RWCS [54] and through irrigation water. However, to build up the soil fertility on long term basis the application of potassium is advisable in RWCS [8].

\section{Conclusions and Recommendation}

Productivity of rice and wheat in this study varies from field to field and location to location. Our study suggested that locations like Nainital, Pakur, Katni, Samba, and Dindori are located outside the IGP, a food granary of India, which might be the major contributors to India's food basket in the near future. Both the crops in RWCS responded well to balance fertilization at all the locations. However, the response of applied fertilizers was poor in high productivity zone as compared to low productivity zone as in high productivity area farmers already uses higher fertilizers as compare to low productivity zone. Hence, extension functionary should create the awareness among the farmers for proper crop management and timely sowing and planting of wheat and rice in low productivity zone. The balance fertilization should be in center for crop management strategies in RWCS. In higher productivity zones, research should be focused on improving nutrient-use efficiency through proper agronomic management practices. 
Author Contributions: Conceptualization, A.S.P. and N.R.; Methodology, D.K.S. and J.S.B.; Software, M.S., S.B. and N.M.A.; Validation, J.S.B., N.R. and L.J.D., and; Formal Analysis, S.B., A.K.P. and J.K.; Investigation, A.S.P. and N.R.; Resources, J.S.B., M.T.S., M.D.L.P. and L.J.D.; Data Curation, S.B., L.N.D. and N.M.A.; Writing-Original Draft Preparation, S.B. and M.S.; Writing-Review \& Editing, A.S.P., N.R. and S.C.; Visualization, A.S.P.; Supervision, N.R. and M.S.; Project Administration, A.S.P.

Funding: This research was funded by Indian Council of Agricultural Research-Indian Institute of Farming Systems Research, Modipuram, UP, India.

Acknowledgments: The authors are thankful to the Chief Agronomists/and researchers of on-farm experiments (OFR-1) of All India Coordinated Research Project on Integrated Farming Systems (AICRP-IFS) of Amritsar, Samba, Nainital, Kanpur, Ambedkarnagar Pakur, Katni, and Dindori for cooperation in conducting the on-farm experimentation in their respective jurisdiction and providing the data.

Conflicts of Interest: The authors declare no conflicts of interest.

\section{References}

1. Ladha, J.K.; Singh, Y.; Erenstein, O.; Hardy, B. Integrated Crop and Resource Management in the Rice-Wheat System of South Asia; Asian Development Bank: Los Banos, Philippines, 2009.

2. Singh, V.K.; Dwivedi, B.S.; Buresh, R.J.; Jat, M.L.; Majumdar, K.; Gangwar, B.; Govil, V.; Singh, S.K. Potassium fertilization in rice-Wheat system across Northern India: Crop performance and soil nutrients. Agron. J. 2013, 105, 471-481. [CrossRef]

3. Shweta; Malik, M. Improving wheat productivity in rice-wheat cropping system through crop establishment methods. Int. J. Pure Appl. Biosci. 2017, 5, 575-578. [CrossRef]

4. Memon, M.S.; Guo, J.; Tagar, A.A.; Perveen, N.; Ji, C.; Memon, S.A.; Memon, N. The effects of tillage and straw incorporation on soil organic carbon status, rice crop productivity, and sustainability in the rice-wheat cropping system of eastern China. Sustainability 2018, 10, 961. [CrossRef]

5. Singh, M. Yield gap and production constraints in rice-wheat system: Scenario from eastern Uttar Pradesh. Bangladesh. J. Agric. Res. 2011, 36, 623-632. [CrossRef]

6. Government of India. Agricultural Statistics at a Glance, Directorate of Economics and Statistics; Department of Agriculture and Cooperation, Ministry of Agriculture: New Delhi, India, 2010.

7. Dwivedi, B.S.; Shukla, A.K.; Singh, V.K.; Yadav, R.L. Improving nitrogen and phosphorus use efficiencies through inclusion of forage cowpea in rice-wheat systems in the Indo-Gangetic plains of India. Field Crops Res. 2003, 84, 399-418. [CrossRef]

8. Yadav, R.L. Assessing on-farm efficiency and economics of fertilizers N, P and K in rice-wheat system of India. Field Crops Res. 2003, 81, 39-51. [CrossRef]

9. UNEP. Fresh Water Under Threat, South Asia, Vulnerability Assessment of Freshwater Resources to Environmental Change; United Nations Environment Program: Nairobi, Kenya, 2008.

10. Sharma, S.K. Characterization and Mapping of Rice-Wheat System: Its Changes and Constraints to System Sustainability; Final Report for National Agricultural Technology Project, Irrigated Agro-Ecosystem Production Systems Research (PSR 4.1); Project Directorate for Cropping Systems Res.: Meerut, India, 2003.

11. Hegde, D.M.; Dwivedi, B.S. Nutrient management in rice-wheat cropping system in India. Fertil. News 1992, $37,27-41$.

12. Ladha, J.K.; Dawe, D.; Pathak, H.; Padre, A.T.; Yadav, R.L.; Bijay, S.; Singh, Y.; Singh, P.; Kundu, A.L.; Sakal, R.; et al. How extensive are yield declines in long-term rice-Wheat experiments in Asia? Field Crops Res. 2003, 81, 159-180. [CrossRef]

13. Singh, V.K.; Dwivedi, B.S.; Shukla, A.K.; Chauhan, Y.S.; Yadav, R.L. Diversification of rice with pigeon pea in a rice-wheat cropping system on a Typic Ustochrept: Effect on soil fertility, yield and nutrient use efficiency. Field Crops Res. 2005, 92, 85-105. [CrossRef]

14. Ravisankar, N.; Gangwar, B.; Prasad, K. Influence of balanced fertilization on productivity and nutrient use efficiency of cereal based cropping systems. Indian J. Agric. Sci. 2014, 84, 248-254.

15. Cassman, K.G.; De Datta, S.K.; Olk, D.C.; Alcantara, J.; Samson, M.; Descalsota, J.; Dizon, M. Yield decline and nitrogen balance in long-term experiments on continuous, irrigated rice systems in the tropics. Adv. Soil Sci. 1994, 181-222, special issue. 
16. Singh, V.K.; Tiwari, R.; Gill, M.S.; Sharma, S.K.; Tiwari, K.N.; Dwivedi, B.S.; Shukla, A.K.; Mishra, P.P. Economic viability of site-specific nutrient management in rice-wheat cropping. Better Crops-India 2008, 2 , $16-19$.

17. Bhatt, R.; Kukal, S.S.; Busari, M.A.; Arora, S.; Yadav, M. Sustainability issues on rice-Wheat cropping system. Int. Soil Water Conserv. Res. 2016, 4, 64-74. [CrossRef]

18. Humphreys, E.; Kukal, S.S.; Christen, E.W.; Hira, G.S.; Singh, B.; Yadav, S.; Sharma, R.K. Halt in the ground water decline in north-west India-which crop technologies will be winners? Adv. Agron. 2010, 109, 156-199.

19. Sapkota, T.B.; Jat, R.K.; Singh, R.G.; Jat, M.L.; Stirling, C.M.; Jat, M.K.; Bijarniya, D.; Kumar, M.; Singh, Y.; Saharawat, Y.S.; et al. Soil organic carbon changes after seven years of conservation agriculture in a rice-wheat system of the eastern Indo-Gangetic Plains. Soil Use Manag. 2017, 33, 81-89. [CrossRef]

20. Bhandari, A.L.; Ladha, J.K.; Pathak, H.; Padre, A.T.; Dawe, D.; Gupta, R.K. Yield and soil nutrient changes in a long-term rice-Wheat rotation in India. Soil Sci. Soc. Am. 2002, 66, 162-170. [CrossRef]

21. Dar, M.; Aggarwal, R.; Samanpreet. Effect of climate change scenarios on yield and water balance components in rice-wheat cropping system in Central Punjab, India. J. Agrometeorol. 2017, 19, 226-229.

22. Chaudhary, M.K.; Harrington, L.W. The Rice-Wheat Systems in Haryana: Input-Output Trends and Sources of Future Productivity Growth; CIMMYT, Mexico, DF, C.C.S; Haryana Agricultural University Regional Research Station: Karnal, India, 1993.

23. Aggarwal, G.C.; Sidhu, A.S.; Sekhon, N.K.; Sandhu, K.S.; Sur, H.S. Puddling and N management effects on crop response in a rice-wheat cropping system. Soil Till. Res. 1995, 36, 129-139. [CrossRef]

24. Dwivedi, B.S.; Shukla, A.K.; Singh, V.K.; Yadav, R.L. Results of participatory diagnosis of constraints and opportunities (PDCO) based trials from the state of Uttar Pradesh. In Development of Farmers' Resource-Based Integrated Plant Nutrient Supply Systems: Experience of an FAO-ICAR-IFFCO Collaborative Project and AICRP on Soil Test Crop Response Correlation; Subba Rao, A., Srivastava, S., Eds.; IISS: Bhopal, India, 2001; pp. 50-75.

25. Mandal, T.; Chandra, S.; Singh, G. Productivity and economics of rice-wheat cropping system under irrigation, nutrient and tillage practices in a silty clay loam soil. Int. J. Curr. Microbiol. Appl. Sci. 2018, 7, 823-831. [CrossRef]

26. Prasad, R. Zinc in soils and in plant, human and animal nutrition. Indian J. Fertil. 2006, 2, 103-119.

27. Dwivedi, B.S.; Singh, V.K.; Meena, M.C.; Dey, A.; Datta, S.P. Integrated nutrient management for enhancing nitrogen use efficiency. Indian J. Fertil. 2016, 12, 62-71.

28. Singh, B.; Singh, Y.; Sekhon, G.S. Fertilizer N use efficiency and nitrate pollution of groundwater in developing countries. J. Contam. Hydrol. 1995, 20, 167-184. [CrossRef]

29. Dwivedi, B.S.; Tewatia, R.K.; Meena, M.C. Fertiliser policy and nutrient management: How to connect? In Book of Extended Summaries. National Dialogue on Efficient Management for Improving Soil Health; Jat, M.L., Majumdar, K., McDonald, A., Sikka, A.K., Paroda, R.S., Eds.; TAAS, ICAR, CIMMYT, IPNI, CSISA, FAI: New Delhi, India, 2015; pp. 23-25.

30. Dwivedi, B.S.; Singh, V.K.; Shekhawat, K.; Meena, M.C.; Dey, A. Enhancing use efficiency of phosphorus and potassium under different cropping systems of India. Indian J. Fertil. 2017, 13, 20-41.

31. Tandon, H.L.S. Soil nutrient balance sheetsin India: Importance, status, issues, and concerns. Better Crops 2007, 1, 15-19.

32. Majumder, B.; Mandal, B.; Bandyopadhyay, P.K.; Gangopadhyay, A.; Mani, P.K.; Kundu, A.L.; Mazumdar, D. Organic amendments influence soil organic carbon pools and rice-Wheat productivity. Soil Sci. Soc. Am. J. 2008, 72, 775-785. [CrossRef]

33. Katyal, J.C. Soil fertility management-A key to prevent desertification. J. Ind. Soc. Soil Sci. 2003, 51, 378-387.

34. Shukla, A.K.; Dwivedi, B.S.; Singh, V.K.; Gill, M.S. Macro role of micronutrients. Indian J. Fertil. 2009, 5, 11-30.

35. Buresh, R.J.; Pampolino, M.F.; Witt, C. Field-specific potassium and phosphorus balances and fertilizer requirement for irrigated rice-based cropping systems. Plant Soil. 2010, 335, 35-64. [CrossRef]

36. Pezzuolo, A.; Basso, B.; Marinello, F.; Sartori, L. Using SALUS model for medium and long term simulations of energy efficiency in different tillage systems. Appl. Math. Sci. 2014, 8, 6433-6445. [CrossRef]

37. Subash, N.; Mohan, H.S.R. Evaluation of the impact of climatic trends and variability in rice-wheat system productivity using cropping system model DSSAT over the Indo-Gangetic Plains of India. Agric. For. Meteorol. 2012, 164, 71-81. [CrossRef] 
38. Yadav, G.S.; Das, A.; Lal, R.; Babu, S.; Meena, R.S.; Patil, S.B.; Saha, P.; Datta, M. Conservation tillage and mulching effects on the adaptive capacity of direct-seeded upland rice (Oryza sativa L.) to alleviate weed and moisture stresses in the North Eastern Himalayan. Arch. Agron. Soil Sci. 2018, 64, 1254-1267. [CrossRef]

39. Subbiah, B.V.; Asija, G.L. A rapid procedure for the determination of available nitrogen in soils. Curr. Sci. 1956, 25, 259-260.

40. Olsen, S.R.; Cole, C.V.; Watanabe, F.S.; Dean, L.A. Estimation of Available Phosphorus in Soils by Extraction with Sodium Bicarbonate; USDA Circ. 939; USDA: Washington, DC, USA, 1954.

41. Helmke, P.A.; Sparks, D.L. Lithium, sodium, potassium, rubidium, and cesium. In Methods of Soil Analysis; Part 3. Chemical Methods. SSSA Book Series No. 5; SSSA: Madison, WI, USA, 1996; pp. 551-574.

42. Gomez, K.A.; Gomez, A.A. Statistical Procedures for Agricultural Research; John Wiley \& Sons: Singapore, 1984.

43. Aggarwal, P.K.; Kalra, N. Analyzing the limitations set by climatic factors, genotype and water and nitrogen availability on productivity of wheat. II. Climatically potential yields and management strategies. Field Crops Res. 1994, 38, 93-103. [CrossRef]

44. Sapkota, T.B.; Shankar, V.; Rai, M.; Jat, M.L.; Stirling, C.M.; Singh, L.K.; Jat, H.S.; Grewal, M.S. Reducing global warming potential through sustainable intensification of basmati rice-wheat systems in India. Sustainability 2017, 9, 1044. [CrossRef]

45. Gupta, R.K.; Hobbs, P.R.; Ladha, J.K.; Prabhakar, S.V.R.K. Resource Conserving Technologies: Transferring the Rice-Wheat Systems of the Indo-Gangetic Plains; Asia-Pacific Association of Agricultural Research Association, APAARI Publication: Bangkok, Thailand, 2000; Volume 42.

46. Singh, K.M.; Singh, H.K.; Sohane, R.K.; Singh, A. Performance of wheat cultivars under irrigated late sown condition. J. Exp. Biol. Agric. Sci. 2017, 5, 472-475. [CrossRef]

47. Jat, M.L.; Saharawat, Y.S.; Gupta, R. Conservation agriculture in cereal systems of South Asia: Nutrient management perspective. Karnataka J. Agric. Sci. 2011, 24, 100-105.

48. Casman, K.G.; Gines, G.C.; Dizon, M.A.; Samson, M.I.; Al-cantara, J.M. Nitrogen-Use efficiency in tropical low land rice systems: Contributions from indigenous and applied nitrogen. Field Crops Res. 1996, 47, 1-2. [CrossRef]

49. Smith, P.T.; Cobb, B.G. Physiological and enzymatic activity of pepper seeds (Capsicum annum) during priming. Physiol. Plant. 1991, 82, 433-439. [CrossRef]

50. Debnath, S.; Pachauri, S.P.; Srivastava, P.C. Improving use efficiency of applied phosphorus fertilizer by zinc fertilization in Basmati rice-wheat cropping system. Indian J. Agric. Res. 2015, 49, 414-420. [CrossRef]

51. Rekhi, R.S.; Benbi, D.K.; Singh, B. Effect of fertilizers and organic manures on crop yields and soil properties in rice-Wheat cropping system. In Long-Term Soil Fertility Experiments in Rice-Wheat Cropping Systems; Rice-Wheat Consortium Paper Series 6; Abrol, I.P., Bronson, K.F., Duxbury, J.M., Gupta, R.K., Eds.; Rice-Wheat Consortium for the Indo-Gangetic Plains: New Delhi, India, 2000; pp. 1-6.

52. Tiwari, K.N.; Dwivedi, B.S.; Subba Rao, A. Potassium management in rice-wheat system. In Rice-Wheat Cropping System, Proceedings of the Rice-Wheat Workshop, Meerut, India, 15-16 October 1990; Project Directorate for Cropping Systems Res.: Meerut, India, 1992; pp. 93-114.

53. Regmi, A.P.; Ladha, J.K.; Pasuquin, E.; Pathak, H.; Hobbs, P.R.; Shrestha, L.L. The role of potassium in sustaining yields in a long-term rice-Wheat experiment in the Indo-Gangetic Plains of Nepal. Biol. Fertil. Soils 2002, 36, 240-247.

54. Rao, A.S.; Reddy, K.S. Integrated nutrient management vis-à-vis crop production/productivity, nutrient balance, farmer livelihood and environment: India. In Proceedings of the Regional Workshop, Beijing, China, 12-16 December 2005.

(C) 2018 by the authors. Licensee MDPI, Basel, Switzerland. This article is an open access article distributed under the terms and conditions of the Creative Commons Attribution (CC BY) license (http://creativecommons.org/licenses/by/4.0/). 